\title{
Upper Jurassic carbonate buildups in the Miechów Trough, southern Poland - insights from seismic data interpretations
}

\author{
Lukasz Słonka and Piotr Krzywiec \\ Institute of Geological Sciences, Polish Academy of Sciences (IGS PAS), Twarda Street 51/55, 00-818 Warsaw, Poland
}

Correspondence: Łukasz Słonka (lukasz.slonka@twarda.pan.pl)

Received: 17 November 2019 - Discussion started: 18 December 2019

Revised: 14 May 2020 - Accepted: 31 May 2020 - Published: 1 July 2020

\begin{abstract}
The geometry and internal architecture of the Upper Jurassic carbonate depositional system in the epicontinental basin of central and western Europe and within the northern margin of the Tethyan shelf are hitherto only partly recognized, especially in areas with thick Cretaceous and younger cover such as the Miechów Trough. In such areas, seismic data are indispensable for the analysis of a carbonate depositional system, in particular for the identification of the carbonate buildups and the enveloping strata. The study area is located in the central part of the Miechów Trough that in the Late Jurassic was situated within the transition zone between the Polish part of the central and western European epicontinental basin and the Tethys Ocean. This paper presents the results of the interpretation of 2D seismic data calibrated by deep wells that document the presence of large Upper Jurassic carbonate buildups. The lateral extent of particular structures is in the range of 400-1000 m, and their heights are in the range of $150-250 \mathrm{~m}$. The interpretation of seismic data revealed that the depositional architecture of the subsurface Upper Jurassic succession in the Miechów Trough is characterized by the presence of large carbonate buildups surrounded by basinal (bedded) limestone and marly-limestone deposits. These observations are compatible with depositional characteristics of well-recognized Upper Jurassic carbonate sediments that crop out in the adjacent Kraków-Częstochowa Upland. The presented study provides new information about carbonate open-shelf sedimentation within the transition zone in the Late Jurassic, which proves the existence of a much more extensive system of organic buildups which flourished in this part of the basin. The results obtained, due to the high quality of available seismic data, also provide an excellent generic reference point for
\end{abstract}

seismic studies of carbonate buildups in other basins and of different ages.

\section{Introduction}

Carbonate buildups display considerable vertical accretion to adapt to a gradual, relative sea level rise (e.g. Kendall and Schlager, 1981; Read, 1985; Sarg, 1988; Handford and Loucks, 1993; Schlager, 2005). The term "carbonate buildup", often used in seismic stratigraphic studies, refers to all "carbonate deposits that form positive bathymetric features" (Bubb and Hatlelid, 1977). Seismic data proved to be very useful for the identification of carbonate buildups because they can clearly show the differences in depositional characteristics between the buildup and the enveloping strata. Carbonate beds are often related to relatively high reflectivity of seismic data. Lateral and vertical variations of this reflectivity (including amplitude and frequency characteristics, continuity of seismic horizons, etc.) and related considerable differences in seismic velocities of particular rock packages are related to different lithologies within the carbonate buildups and surrounding deposits (see Fontaine et al., 1987, and Macurda, 1997, for an overview of seismic facies analysis of carbonate rocks).

The seismic expression of carbonate buildups may be rather diverse (Fig. 1). The classic interpretation, established during the period of intense development of seismic stratigraphy in the late 1970s, assumes several recognition criteria, such as (1) the mound-shaped reflection configuration pattern, (2) lateral seismic facies changes between the buildups and enveloping beds, (3) reflections from the edges of buildups including hyperbolic diffractions, (4) onlap of 


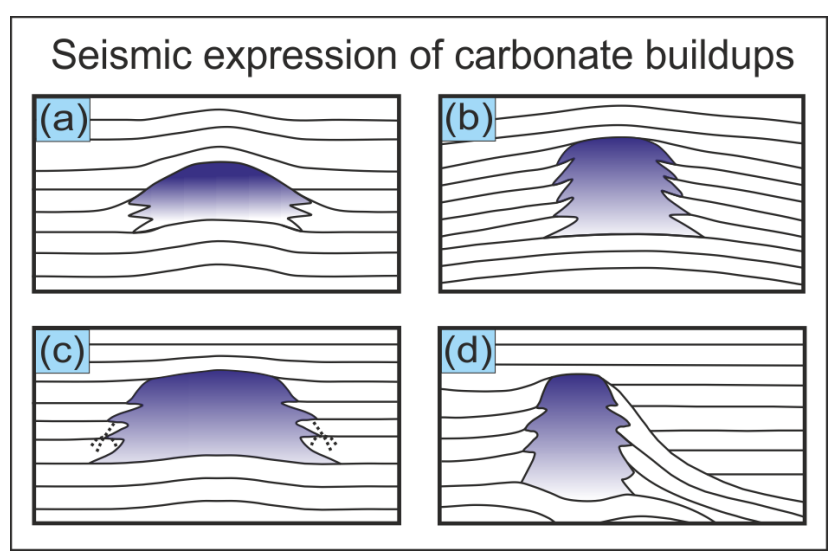

Figure 1. Common types of seismic expression of carbonate buildups used for their seismic identification and characteristics (based on Bubb and Hatlelid, 1977; Veeken and Van Moerkerken, 2013; modified): (a) velocity pull-up and differential compaction, (b) reflection-free with drape effect, (c) reflection-free with diffractions on edge, and (d) compaction sag and transgressive onlap.

overlying strata, (5) drape effects over the buildups and (6) the velocity pull-up anomalies, as well as other criteria (e.g. Bubb and Hatlelid, 1977; Veeken and Van Moerkerken, 2013; Burgess et al., 2013). Furthermore, differential compaction (manifested by so-called compaction sag) might indicate the presence of a carbonate buildup in seismic data.

Numerous papers dealing with various aspects of the seismic interpretation of carbonate buildups of different ages have been published over the years, which concern various sedimentary basins such as, for example, the Great Bahama Bank (e.g. Eberli et al., 2004), the Maldives (e.g. Belopolsky and Droxler, 2004), southern Oman (e.g. Borgomano et al., 2004), northern Australia (e.g. Isern et al., 2004; Rosleff-Soerensen et al., 2012; Saqab and Bourget, 2016; Van Tuyl et al., 2018, 2019), the Black Sea region (e.g. Afanasenkov et al., 2007; Guo et al., 2011), offshore southern Norway (e.g. Philips et al., 2019), the Barents Sea, Norway (e.g. Blendinger et al., 1997; Elvebakk et al., 2002; Colpaert et al., 2007; Rafaelsen et al., 2008; Di Lucia et al., 2017; Sayago et al., 2018), the Philippines (e.g. Grötsch and Mercadier, 1999; Neuhaus et al., 2004; Fournier et al., 2004, 2005; Fournier and Borgomano, 2007), South China Sea (e.g. Wu et al., 2009; Yubo et al., 2011; Chang et al., 2017), offshore Indonesia and Malaysia (e.g. Epting, 1989; Kusumastuti et al., 2002; Zampetti et al., 2003, 2004; Bachtel et al., 2004; Posamentier et al., 2010; Koša, 2015), and the Indus Basin (Shahzad et al., 2018, 2019). In contrast, relatively few seismic examples of Upper Jurassic carbonate buildups from the classic, geologically well-recognized central and western European northern Tethyan shelf and the surrounding region have been published to date (e.g. Ellis et al., 1990; Zimmer and Wessely, 1996; Adámek, 2005; Wessely, 2006; Buness et al., 2010; Hartmann et al., 2012; Lüschen et al.,

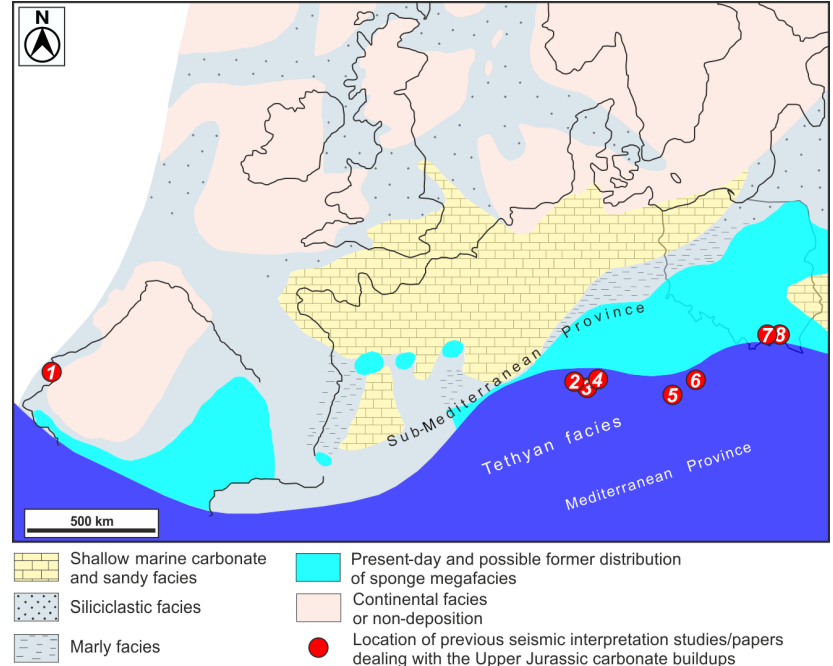

Figure 2. Simplified palaeogeographic sketch map of central and western Europe for the middle-late Oxfordian (based on Wierzbowski et al., 2016); red points show the location of the previously published seismic interpretation studies/papers dealing with the Upper Jurassic carbonate buildups from the northern Tethyan shelf margin and adjacent areas (1. Ellis et al., 1990; 2. Buness et al., 2010; 3. Hartmann et al., 2012; 4. Lüschen et al., 2014; 5. Zimmer and Wessely, 1996; 6. Adámek, 2005; 7. Gliniak and Urbaniec, 2001; 8. Gliniak et al., 2005; see text for more details).

2014; Fig. 2). In Poland also, only a few papers on the seismic interpretation of Upper Jurassic carbonate buildups have been published so far, usually in local journals and focused mostly on exploration-related problems (Gliniak et al., 2000, 2001, 2005; Gliniak and Urbaniec, 2001, 2005; Misiarz, 2003; Misiarz et al., 2004; Jędrzejowska-Tyczkowska et al., 2005, 2006; Myśliwiec et al., 2006). Recently, several new buildups have been identified and interpreted using seismic data (Urbaniec, 2019). However, those results represent the more southerly part of the basin, located beneath the Miocene of the Carpathian Foredeep Basin (about $50 \mathrm{~km}$ to the south of the study area).

This study fills this gap and provides a well-documented example of a system of carbonate buildups developed in the south-eastern segment of the transition zone between the European Late Jurassic epicontinental basin and the Tethys Ocean. Results presented in this paper could also be used as a more universal reference point for seismic studies of carbonate depositional systems - in particular of carbonate buildups and surrounding deposits - of different ages and from different sedimentary basins.

The study area is located in the central part of the Miechów Trough, southern Poland, approximately $50 \mathrm{~km}$ north-east of Kraków, in the vicinity of the town of Pińczów (Fig. 3). In this area, the geometry and depositional architecture of the Upper Jurassic carbonate succession are relatively poorly recognized in comparison to adjacent parts of the basin in 
Poland and central and western Europe. This is mostly due to the fact that the Jurassic succession is covered by relatively thick Cretaceous and younger deposits; hence, previous studies were based almost entirely on data from deep research wells (cf. Złonkiewicz, 2006, 2009).

In 2011, the Upper Jurassic carbonate succession in the study area was drilled by two exploratory wells: Chopin1 and Belvedere-1. These two wells, together with three archive wells located in this area, were used to calibrate a relatively dense coverage of $2 \mathrm{D}$ seismic reflection profiles. Synthetic seismograms were used to precisely tie wells to seismic profiles, and the seismic-stratigraphic approach was used to analyse the depositional architecture of the Upper Jurassic carbonate system, including carbonate buildups and surrounding deposits.

\section{Geological setting}

\subsection{The Permian-Mesozoic Polish Basin: an overview}

The study area is located within the central part of the Miechów Trough (Fig. 3), which forms the south-eastern part of the Szczecin-Łódź-Miechów Synclinorium (Żelaźniewicz et al., 2011), which was formed during the Late Cretaceous-Paleogene inversion of the Permian-Mesozoic Polish Basin.

The Permian-Mesozoic Polish Basin formed the easternmost part of a system of epicontinental basins in central and western Europe (Ziegler, 1990; Scheck-Wenderoth et al., 2008; Pharaoh et al., 2010). Its most subsiding axial part - the Mid-Polish Trough - evolved along the NW- to SEtrending Teisseyre-Tornquist Zone (see Mazur et al., 2015, for a recent summary and further references). The southeastern part of the Polish Basin extended into the transition zone towards the Tethyan domain, characterized by limited Permian and Triassic sedimentation. Since the Jurassic, the thickness and depositional pattern in this part of the basin were affected by tectonic processes acting within the Polish Basin and by increased regional subsidence in the Tethyan domain (e.g. Kutek and Głazek, 1972; Pożaryski and Żytko, 1981; Feldman-Olszewska, 1997a, b; Marek and Pajchlowa, 1997; Dadlez et al., 1998; Kutek, 2001; Gutowski et al., 2005; Gutowski and Koyi, 2007; Krzywiec et al., 2009).

The Polish Basin was inverted in the Late CretaceousPaleogene (e.g. Dadlez et al., 1995; Krzywiec, 2002, 2009; Resak et al., 2008; Krzywiec et al., 2009, 2018). This basin inversion was associated with major uplift and erosion of the axial part of the basin (i.e. the Mid-Polish Trough), which was transformed into a regional anticlinal structure - the Mid-Polish Swell (Mid-Polish Anticlinorium; cf. Pożaryski and Brochwicz-Lewiński, 1978, 1979; Żelaźniewicz et al., 2011). Due to inversion-related formation of the MidPolish Swell, two regional synclinoria were formed along both its flanks, including the south-western Szczecin-Łódź-
Miechów Synclinorium in which the Miechów Trough is located (see, e.g., Dadlez et al., 2000; Fig. 3).

\subsection{Late Jurassic basin in S Poland}

The Late Jurassic basin in Poland formed the eastern part of the extensive, shallow epicontinental basin that extended from the United Kingdom, across the Netherlands and Germany, into Poland, and farther into the east (Fig. 2; Ziegler, 1990; Pieńkowski et al., 2008; Lott et al., 2010). Throughout much of the Jurassic, the basin was connected to the Tethys Ocean from the south (Lott et al., 2010; see Pieńkowski et al., 2008, for a detailed overview and further references). The Late Jurassic was a time of extensive development of carbonate buildups in the Tethyan domain and its margins (e.g. Leinfelder et al., 1994, 2002; Matyszkiewicz, 1997a; Krajewski and Schlagintweit, 2018).

In the Late Jurassic, the south-eastern (Peri-Carpathian) segment of the basin was part of the European shelf adjacent to the Tethys Ocean from the north (cf. Ziegler, 1990; Golonka, 2004; Golonka et al., 2000; Gutowski et al., 2005, 2006; Pieńkowski et al., 2008). The main factors that directly or indirectly controlled Late Jurassic sedimentation within the northern Tethyan shelf in southern Poland included sealevel and climate changes and diversified subsidence triggered by the reactivation of older basement faults (e.g. Kutek, 1994; Gutowski et al., 2005; Matyszkiewicz et al., 2012, 2015a, 2016).

The Oxfordian and lower Kimmeridgian succession within the Polish part of the northern Tethyan shelf margin is commonly interpreted as a carbonate ramp or open-shelf deposits (e.g. Matyja et al., 1989; Kutek, 1994; Gutowski et al., 2005; Matyja, 2009; Krajewski et al., 2011; Fig. 4a). These deposits, sometimes termed the sponge megafacies, are built of sponges and microbialites and are present within the entire European part of the northern Tethyan shelf margin (Gwinner, 1971; Matyja, 1977; Matyja and Pisera, 1991; Matyja and Wierzbowski, 1995, 1996, 2006; cf. Matyszkiewicz, 1997a; Gutowski et al., 2005, 2006).

Widespread carbonate sedimentation took place in the Oxfordian (upper Transversarium-Bifurcatus and Planula zones), when diverse reef facies developed (Fig. 4a; e.g. Matyszkiewicz et al., 2012, 2015b, 2016; Krajewski et al., 2016, 2018). Several authors claim that the development of carbonate platforms in this part of Europe may have been connected to the middle Oxfordian (Transversarium zone) climate warming (Krajewski et al., 2017; see Leinfelder et al., 1996; Matyszkiewicz, 1997a; Olivier et al., 2011; Wierzbowski, 2015). The Upper Jurassic carbonate buildups in southern Poland display a large diversity of reef types, from siliceous sponge mounds to microbial-sponge buildups and coral reefs, as all of these types were commonly found in Europe where reefs were most widespread in the Late Jurassic (Kiessling et al., 1999; cf. Leinfelder et al., 1996; Gliniak et al., 2005; Matyszkiewicz et al., 2012; 


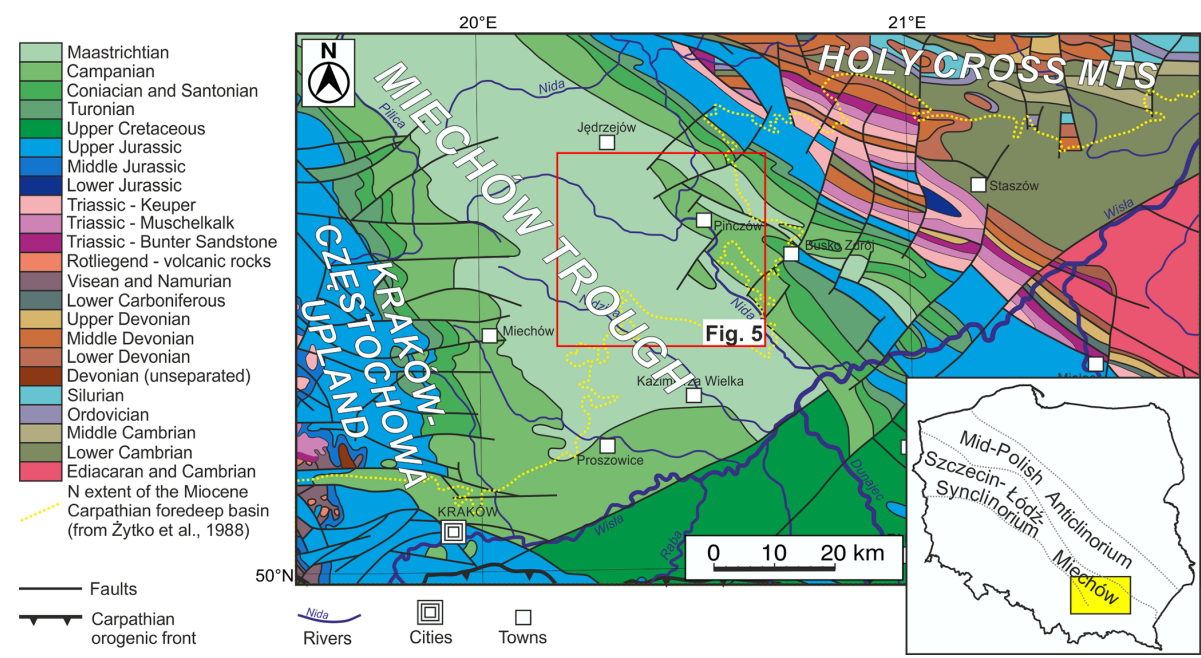

Figure 3. Geological map of the Miechów Trough and the adjacent areas (based on Dadlez et al., 2000; simplified). The inset map shows the location of this unit in Poland (yellow rectangle). The study area is indicated by the red rectangle.

Krajewski et al., 2018). Outside of Europe, reefs occurred less commonly in the Late Jurassic, and they represented mainly coral-dominated reefs and biostromes (Kiessling et al., 1999). Common carbonate buildup types that can be recognized from the seismic data in Poland are bioherms (e.g. Gliniak and Urbaniec, 2001, 2005; Gliniak et al., 2005). Worldwide, these organic structures can be found at all latitudes between $45^{\circ} \mathrm{S}$ and $52^{\circ} \mathrm{N}$ (Kiessling et al., 1999); in southern Poland they often developed as large microbialsponge biohermal complexes (e.g. Matyja and Wierzbowski, 2006).

The Callovian to lower Kimmeridgian (up to the Hypselocyclum zone) deposits of the Polish Basin have been subdivided by Kutek (1994) into two intervals related to distinct stages of tectonic-sedimentary evolution (Krajewski et al., 2017; cf. Kutek, 1994). The first one embraces the Callovian-Oxfordian, including the Planula zone; it is commonly limited to the upper Oxfordian in the subMediterranean subdivisions (e.g. Krajewski et al., 2017). In contrast, the second interval encompasses the lower Kimmeridgian (Platynota and Hypselocyclum zones). Both intervals are separated by the so-called "Lowermost Marly Horizon", which is included in the lower Platynota zone and plays an important role as a regional isochronous marker in stratigraphic correlations of the Upper Jurassic in central and southern Poland (Kutek, 1968, 1994). Between those two intervals, significant facies changes occurred (e.g. Kutek, 1994; Matyszkiewicz, 1996; Krajewski et al., 2017). They are expressed by (1) the disappearance of the Oxfordian organic buildups, (2) platform drowning in the lower Platynota zone linked with the development of marly facies and (3) the occurrence of gravity flow deposits (e.g. Krajewski et al., 2017).

\subsection{The Upper Jurassic succession in the Miechów Trough}

The Upper Jurassic succession of the Miechów Trough is almost entirely covered by Cretaceous deposits, represented by the Albian-lower Maastrichtian (Fig. 3; e.g. Jurkowska, 2016) and, in its south-eastern part, by the Miocene deposits of the Carpathian Foredeep Basin (e.g. Pożaryski, 1977; Żytko et al., 1988; Krzywiec, 2001). From the south-west, the Miechów Trough borders the Kraków-Częstochowa Upland and, from the north-east, the Holy Cross segment of the Mid-Polish Anticlinorium (Fig. 3; cf. Pożaryski, 1974; Żelaźniewicz et al., 2011).

The Upper Jurassic carbonate deposits outcropping along the flanks of the Miechów Trough have been extensively studied for many decades (e.g. Dżułyński, 1952; Kutek, 1968, 1969; Matyja, 1977; Matyja and Tarkowski, 1981; Trammer, 1982, 1985, 1989; Matyszkiewicz, 1989, 1993, 1996, 1997b, 1999, 2001, 2006, 2012, 2015a, 2016; Matyszkiewicz and Felisiak, 1992; Matyja and Wierzbowski, 1996, 2006; Matyja et al., 1989, 2006; Krajewski et al., 2011, 2016, 2017, 2018). Numerous studies dealing with detailed aspects of the Upper Jurassic stratigraphy and sedimentology have also been carried out in the more south-easterly part of the Miechów Trough, including its extension towards the Carpathian Foredeep south of the Wisła river (cf. Fig. 3; Morycowa and Moryc, 1976, 2011; Golonka, 1978; Gliniak et al., 2004; Gutowski et al., 2005, 2007; Matyja and Barski, 2007; Matyja, 2009; Olszewska et al., 2012).

The Upper Jurassic succession in the Miechów Trough is represented by various carbonate ramp-type platform facies (e.g. Kutek, 1968, 1969; Matyja et al., 1989, 2006; Gutowski et al., 2005, 2006; Matyja, 2009; Złonkiewicz, 2009; Krajewski et al., 2017; Fig. 4a). According to Złonkiewicz (2009), the Callovian and Upper Jurassic deposits in the Miechów 


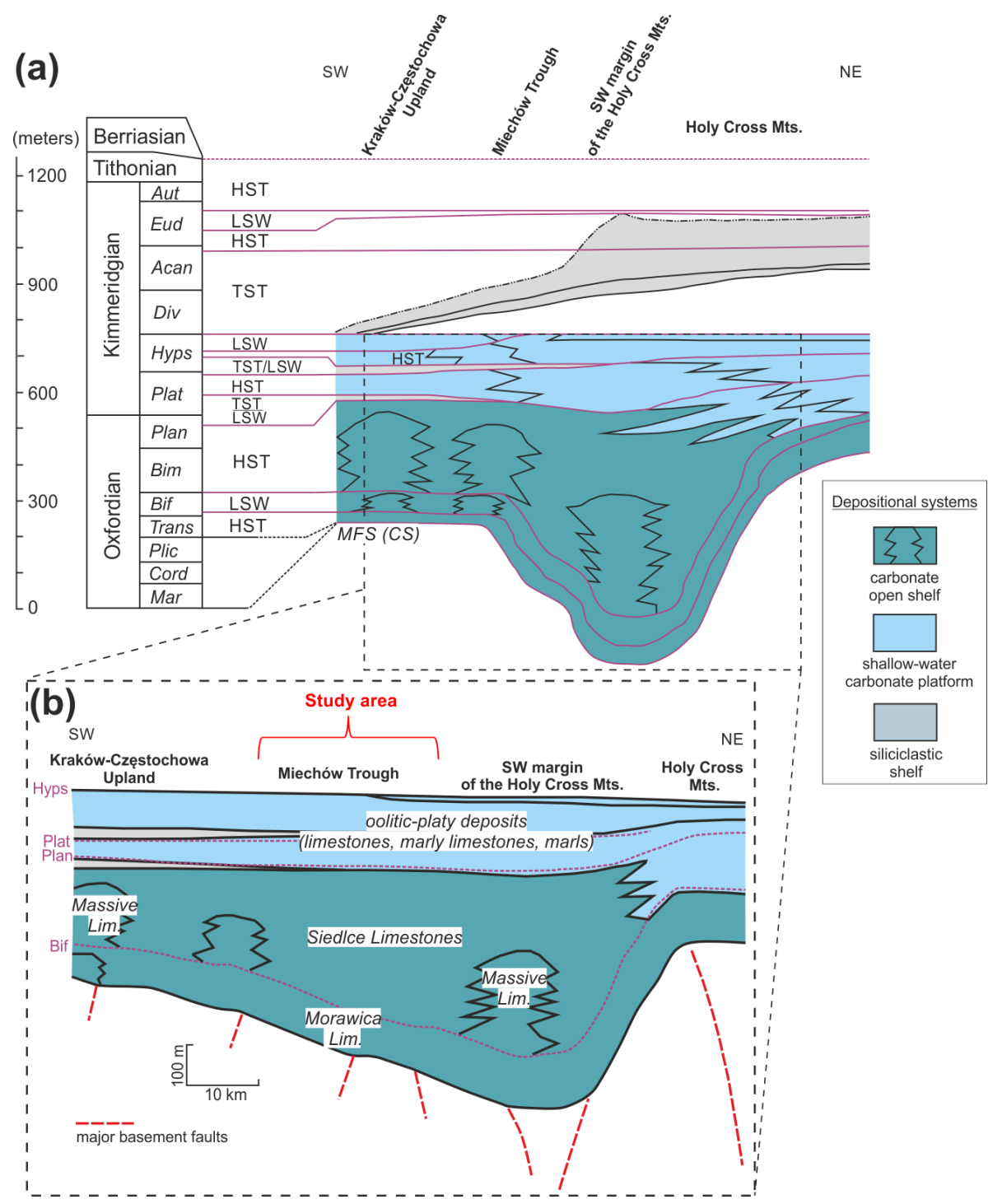

Figure 4. (a) Simplified, idealized stratigraphic scheme of the Late Jurassic epicontinental basin in southern Poland including the Miechów Trough and showing main depositional systems and cyclicity (based on Gutowski et al., 2005). Sub-Mediterranean ammonite zones abbreviations: Mar - Mariae, Cor - Cordatum, Plic - Plicatilis, Trans - Transversarium, Bif - Bifurcatus, Bim - Bimammatum, Plan - Planula, Plat Platynota, Hyps - Hypselocyclum, Div - Divisium, Acan - Acanthicum, Eud - Eudoxus, Aut - Autissiodorensis); system tract abbreviations: HST - highstand, LSW - lowstand wedge, TST - transgressive, MFS (CS) - maximum flooding surface (condensed section). (b) Details of the Oxfordian-Kimmeridgian interval showing the main Upper Jurassic lithological units in the study area and adjacent regions (based on Gutowski et al., 2005, 2006; Złonkiewicz, 2009; simplified).

Trough genetically resemble those from the south-western margin of the Holy Cross Mountains (cf. Matyja et al., 1989), which prompted him to adopt almost the same lithostratigraphic correlation scheme (Złonkiewicz, 2009).

During the Late Jurassic, the study area was located on the northern, passive margin of the Tethys Ocean (e.g. Matyja and Wierzbowski, 1995; Golonka, 2004; Matyja, 2009). The sequence stratigraphic scheme for this part of the basin, together with the regional correlation of main depositional systems, was proposed by Gutowski et al. (2005). This scheme can be generally correlated with the main
Oxfordian-Kimmeridgian lithological units in the study area (Złonkiewicz, 2009; Fig. 4a and b). These key Upper Jurassic units include the Morawica limestone member, Siedlce limestone member and massive limestone member (Matyja et al., 1989; Złonkiewicz, 2009; Krajewski et al., 2017; Fig. 4b). Above those carbonate members, deeper-water marly facies are present (Kutek, 1968). They are covered by deposits of the early Kimmeridgian shallow-water carbonate platform, represented by various oolitic-platy facies (Fig. 4b; see Złonkiewicz, 2009, for more details). 
For the south-easternmost part of the Miechów Trough, located beneath the Miocene cover of the Carpathian Foredeep Basin, a detailed subdivision of the Upper Jurassic deposits has been recently proposed using biostratigraphic data (Matyja and Barski, 2007; Barski and Matyja, 2008; Matyja, 2009). According to this stratigraphic scheme, a complete Oxfordian-Valanginian succession is present in the most south-easterly part of the basin with a significantly lower thickness of the Oxfordian-Kimmeridgian deposits than previously assumed and is much more extensive in comparison to other areas of Poland with the stratigraphic range of the sponge megafacies reaching up to the lower Tithonian (Matyja, 2009). Further micro-palaeontological investigations allowed for the stratigraphical reassessment of the Upper Jurassic strata beneath the central part of the Carpathian Foredeep Basin, as well as for the regional correlations towards south-western Ukraine (Olszewska et al., 2012). These findings could possibly also be applied in the future to stratigraphy of the Upper Jurassic succession of the area described in this paper, although this would require extensive studies based on core material that is not currently available.

\section{Data and methods}

\subsection{Well data}

Well calibration for seismic data in this study was provided by the Chopin-1, Belvedere-1, Michałów-3, Węchadłów-1 and Lipówka-1 wells (Fig. 5). Two of these wells, Chopin-1 and Belvedere-1, were drilled in 2011 by the San Leon Energy company (SLE); the other three wells were drilled in the mid-1960s. Therefore, the suitability of well data for detailed seismic analysis was diverse. Both the SLE wells have a wide spectrum of modern well log data, including gamma ray, resistivity, neutron porosity, sonic velocity and density logs, as well as mud logging. They, however, have not been cored, and lithological descriptions are based on cuttings. The data used from three legacy wells included gamma ray, resistivity and sonic logs. All the logs were available as standard LAS files and were loaded into the database used in this study.

Stratigraphic information for the Upper Jurassic succession substantially differs between the older wells and the two newer SLE wells. In the legacy wells, the Upper Jurassic interval was subdivided into Oxfordian, Rauracian and Astartian (Mikucka-Reguła, 1968; Urban and Wandas, 1968; see also Kutek, 1965). Since the late 1960s-early 1970s, the Rauracian and Astartian have been incorporated into the upper Oxfordian (e.g. Morycowa and Moryc, 1976). On the other hand, the Upper Jurassic interval in the SLE Chopin1 and Belvedere-1 wells was subdivided into Oxfordian and Kimmeridgian; this subdivision, however, was based exclusively on lithological criteria derived from well cuttings and well $\log$ interpretations without any biostratigraphical support (Dudek and Wójcik, 2011; Dudek et al., 2011; Lach,

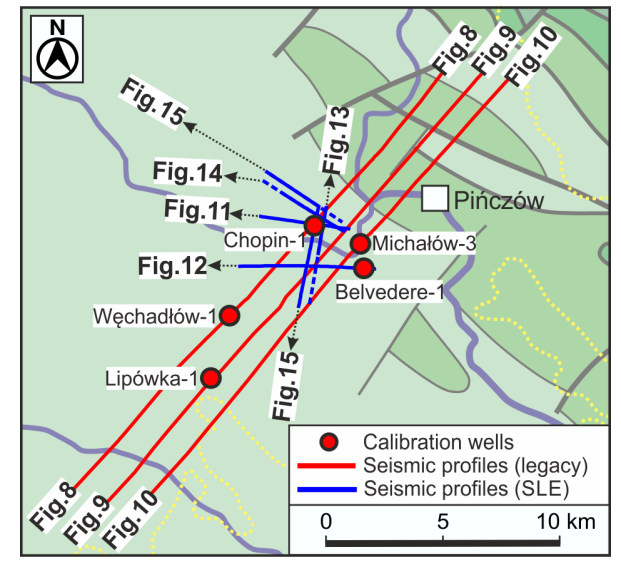

Figure 5. Detailed view of the study area with the location of wells and seismic data. Solid lines (red and blue) mark the sections of the seismic profiles shown in Figs. 8-15. Background geological map (based on Dadlez et al., 2000; Żytko et al., 1988; simplified) from Fig. 3 (see for description).

2011a, b; Szwed and Wójcik, 2011a, b). As a result, formation tops from new and legacy wells are not stratigraphic equivalents.

Because of those ambiguities, the exact stratigraphic position of the Upper Jurassic carbonate buildups analysed in this paper remains unclear. Results of recent biostratigraphic studies from the nearby area indicate that the age of similar carbonate buildups ranges from Oxfordian up to Kimmeridgian and sometimes even up to lower Tithonian (Matyja and Barski, 2007; Matyja, 2009); it could be assumed that similar stratigraphic changes might be needed in the Pińczów area described in this paper. It should be stressed, however, that the precise stratigraphic position of the Upper Jurassic carbonate succession studied does not have any impact on the interpretation of the seismic data presented in this paper; revised stratigraphic schemes might in the future allocate seismically identified carbonate buildups into slightly different Upper Jurassic stratigraphic units.

\subsection{Seismic data}

Two types of seismic data were used in this study: (a) longer legacy profiles acquired in the early 1990s and located in the central part of the Miechów Trough; and (b) short new profiles acquired by SLE in 2011 (Fig. 5). Seismic data were stacked and time migrated, although some seismic artefacts such as diffraction smiles are still visible. Beneath the massive carbonates, a velocity pull-up effect could be observed which is distorting the geometry of the pre-Jurassic basement.

Seismic vertical resolution for the Upper Jurassic interval is $10-20 \mathrm{~m}$ for the SLE profiles and $20-30 \mathrm{~m}$ for the older legacy lines. 


\subsection{Methodology of well and seismic data integration and interpretation}

The precise well to seismic tie was based on synthetic seismograms calculated using sonic and density logs for the key calibration wells: Chopin-1, Belvedere-1 and Michałów-3. The well to seismic tie using synthetic seismograms was also carried out for supporting wells (Węchadłów-1, Lipówka-1); however, due to the lower quality of the sonic logs, the accuracy of this correlation was significantly lower. Synthetic seismograms allowed the correlation of depth well log data (stratigraphy, lithology) with time (TWT) seismic data.

The first phase of seismic data interpretation was carried out for all the seismic profiles. It included the identification of the main stratigraphic horizons (top Palaeozoic, top Triassic, top Middle Jurassic, top Upper Jurassic, top Cenomanian) and the main faults.

The second phase of seismic data interpretation was focused on the Upper Jurassic interval, on details of its depositional architecture and on local fault patterns, and it included an interpretation of all key seismic horizons within the Upper Jurassic succession, analysis of reflection patterns, and recognition of seismic facies related to organic buildups and the surrounding deposits. The seismic-stratigraphic interpretation was carried out for the short SLE lines and partly for the legacy lines in close vicinity to the buildup complexes.

\section{Results}

\subsection{Well to seismic tie}

Synthetic seismograms were calculated using statistical wavelets with a dominant frequency of $30-35 \mathrm{~Hz}$; wavelet length varied between 120 and $150 \mathrm{~ms}$ (Figs. 6 and 7). The two deepest wells (Lipówka-1, Węchadłów-1) that provided information on the top of the Palaeozoic basement, the top of the Triassic and the top of the Middle Jurassic were calibrated by the Michałów-3, Lipówka-1 and Węchadłów-1 wells. Other stratigraphic boundaries - top of the Upper Jurassic (J3) and top of the Cenomanian ( $\mathrm{Kcn}$ ) - were tied to seismic data using data from all five wells used in this study.

\subsection{The 1D seismic stratigraphic analysis}

For the Chopin-1 and Belvedere-1 wells, a detailed 1D seismic stratigraphic analysis was carried out in order to distinguish between the main seismic-stratigraphic units within the Upper Jurassic interval, and to define the relationship between the seismic data, lithology and facies of the Upper Jurassic succession. The seismic stratigraphic 1D analysis was conducted using synthetic seismograms calculated for the Chopin-1 (Fig. 6) and Belvedere-1 wells (Fig. 7). The precise time-depth model derived from the synthetic seismograms allowed for a detailed correlation of formation tops, well log data and lithological profiles with seismic data. The well log data analysed included gamma ray, sonic, density and impedance curves. Lithological profiles for both wells were constructed using well log data and information from core cuttings (Dudek and Wójcik, 2011; Dudek et al., 2011; Lach, 2011a, b; Szwed and Wójcik, 2011a, b).

As a result, the top of the massive limestones, associated with the carbonate buildups, was defined in the seismic data. Furthermore, a correlation of well data with the main depositional systems within the study area following Gutowski et al. (2005) was completed.

Results of the 1D seismic-stratigraphic analysis for the Chopin-1 well are shown in Fig. 6. Formation tops for the Chopin-1 well included the top of the Cenomanian (Kcn), drilled at $587 \mathrm{~m}$, and the top of the Upper Jurassic (J3), drilled at $775 \mathrm{~m}$. The top of the Upper Jurassic is an erosional surface above which the Upper Cretaceous (Cenomanian and younger) rocks were deposited.

The lithological profile for the Chopin-1 well shows that the topmost part (775-843 m) of the Upper Jurassic succession is rather diverse, comprising limestones, marly limestones, marls and claystones (Fig. 6). This lithological diversity is reflected in the variable seismic image - the Upper Jurassic top is related to the high-amplitude positive seismic horizon generated due to a pronounced lithological contrast between the Cenomanian sandstones and the Upper Jurassic limestones. Beneath the Cenomanian, the Chopin-1 well encountered about $41 \mathrm{~m}$ of the Upper Jurassic limestones, which were mostly white to light grey and medium to hard. This interval could be interpreted as a mainly oolitic- and platy-limestone-dominated succession, which is well-known from the Miechów Trough (cf. Złonkiewicz, 2009). Below, a succession of calcareous claystone, marl and marly limestone with a total thickness of about $27 \mathrm{~m}$ is present. Claystones, marls and marly limestones are expressed by high readings on the gamma ray log due to the increased content of clay minerals; thus, this interval (the marly zone in Fig. 6) can at least partly be correlated with the marly facies, including the Lowermost Marly Horizon, of Kutek (1968, 1994). Two lithological intervals described above are characterized by generally high amplitudes of the seismic wave field (Fig. 6) due to strong vertical velocity contrasts between the uppermost limestone package, the marly zone below and frequent alterations of marls and marly limestones. Within the topmost part of the Upper Jurassic succession, the seismic-stratigraphic unit termed J3U was distinguished (Fig. 6). It is characterized by high-amplitude seismic horizons. It corresponds mainly to the oolitic-platy limestone succession (Fig. 6). Within this unit, four seismic horizons have been interpreted: $1 \mathrm{~J} 3 \mathrm{U}, 2 \mathrm{~J} 3 \mathrm{U}, 3 \mathrm{~J} 3 \mathrm{U}$ and $4 \mathrm{~J} 3 \mathrm{U}$. The horizon $1 \mathrm{~J} 3 \mathrm{U}$ corresponds to the very high-amplitude negative reflection that is possibly being interfered with by the Upper Jurassic top horizon above. Its amplitude might also be increased by vertical lithological changes (marl-limestone alternations?) within the oolitic limestone interval, which is marked by a single peak on the gamma ray $\log$. The $2 \mathrm{~J} 3 \mathrm{U}$ 

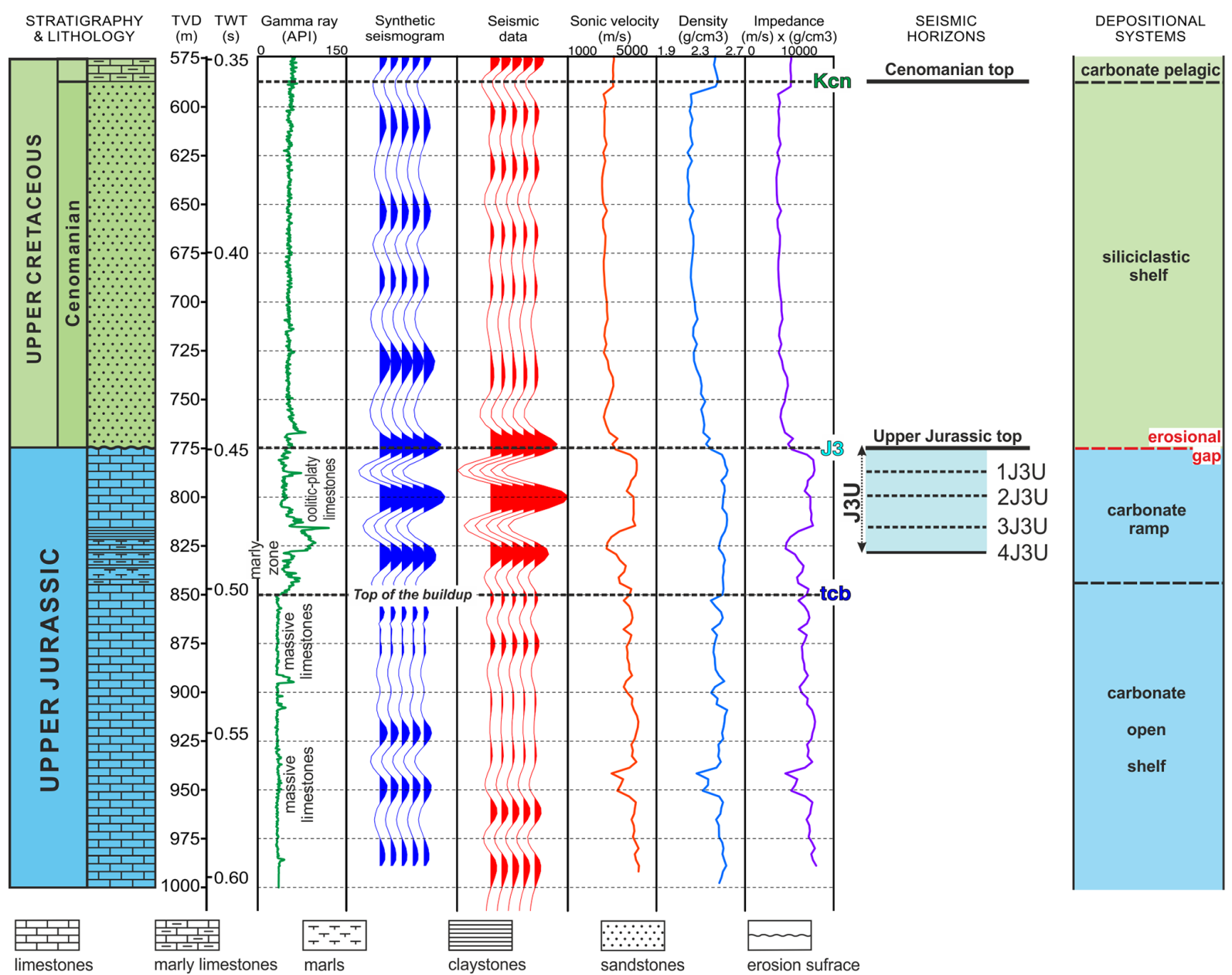

Figure 6. Well to seismic data correlation together with a simplified lithostratigraphic profile for the Upper Jurassic succession and its Cenomanian overburden (Chopin-1 well). The 1D seismic-stratigraphic analysis allowed for the identification of the top of the carbonate buildup deposits (represented by massive limestones - tcb), of the Upper Jurassic (J3) top, of the Cenomanian (Kcn) top, and of four main seismic horizons within the uppermost part of the Upper Jurassic interval located above the buildup deposits (1J3U, 2J3U, 3J3U, 4J3U). Main depositional systems are based on Gutowski et al. (2005) and Krzywiec et al. (2009).

horizon represents a very high-amplitude positive reflection which can be associated with a significant increase in seismic velocities (from about 4500 to $5500 \mathrm{~m} \mathrm{~s}^{-1}$ ) related to the lithological diversity of the oolitic-platy succession. The 3J3U horizon exhibits a high-amplitude negative reflection which corresponds to a sharp lithological contrast between the oolitic limestones and the marl-claystone formation associated with the upper part of the marly zone. The $4 \mathrm{~J} 3 \mathrm{U}$ horizon is expressed by a strong positive reflection related to vertical lithological variations within the lower part of the marly zone (from marls to marly limestones). The interval located between the $3 \mathrm{~J} 3 \mathrm{U}$ and $4 \mathrm{~J} 3 \mathrm{U}$ horizons is characterized by high values on the gamma ray log, which indicate a marly zone. However, because of seismic tuning effects probably caused by frequent marl-limestone alternations, a more precise identification of the marly zone is difficult.
Below the marly zone, a thick (approximately $150 \mathrm{~m}$ ) succession of hard limestones was drilled (Fig. 6). This succession is related to the massive limestones that commonly form carbonate buildups (see, e.g., Matyszkiewicz, 1993; Matyja and Wierzbowski, 2006). The top of the buildup (tcb) on the synthetic seismogram and in seismic data is related to a relatively low-amplitude positive reflector probably due to destructive interference from shallower enveloping boundaries (J3U unit). The massive limestone succession is seismically rather homogeneous (Fig. 6).

In Belvedere-1, the entire Upper Jurassic section located below the top of the carbonate buildup (tcb) is more heterogeneous than in the Chopin-1 well (Fig. 7). The top of the carbonate buildup was located at the top of the massive limestone succession. According to the drilling report (Dudek and Wójcik, 2011; Lach, 2011b), the massive limestone succession could be subdivided into two parts by a package of mod- 


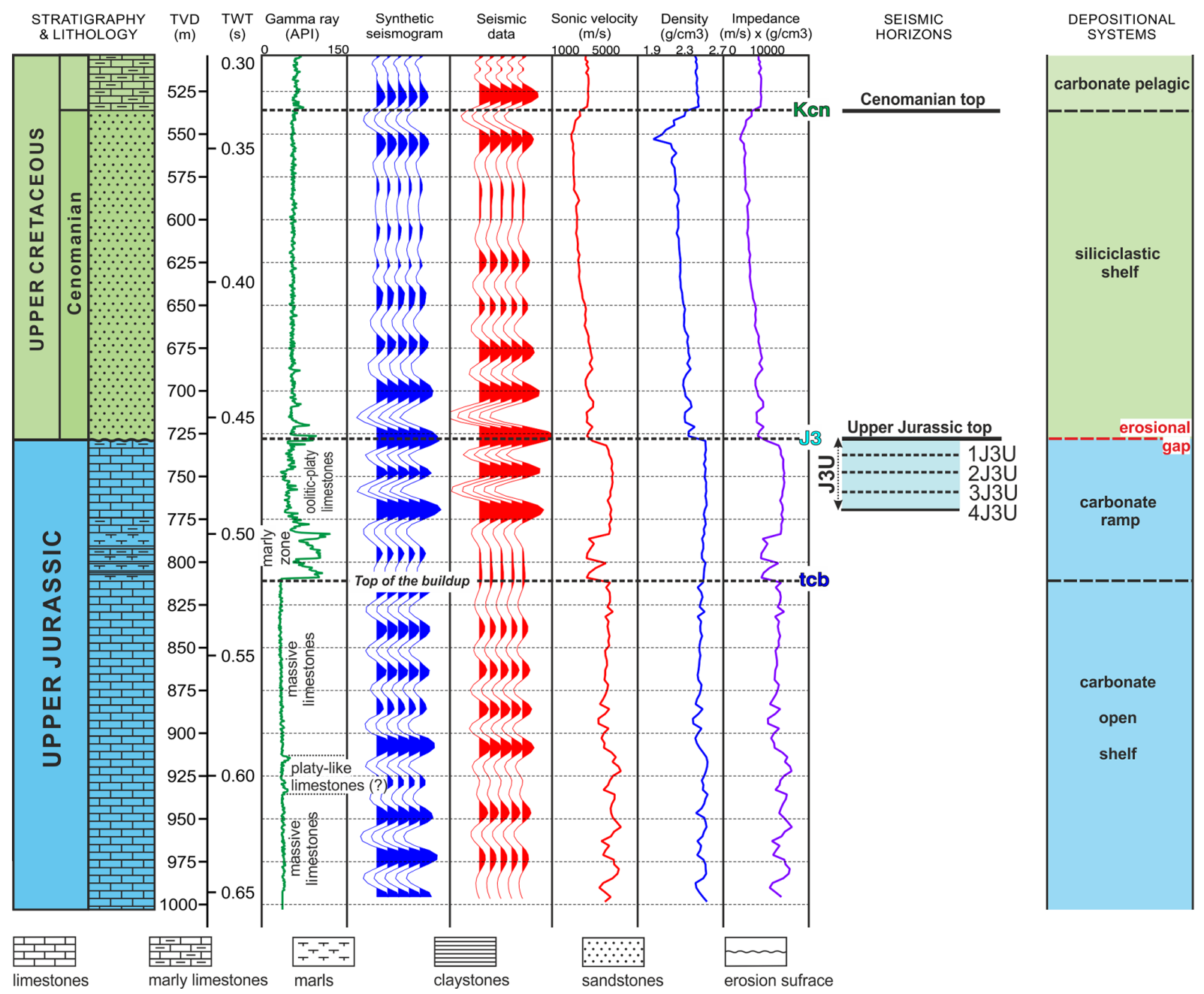

Figure 7. Well to seismic data correlation together with simplified lithostratigraphic profile for the Upper Jurassic succession and its Cenomanian overburden (Belvedere-1 well). The 1D seismic-stratigraphic analysis allowed for the identification of the top of carbonate buildup deposits (represented by massive limestones - tcb), of the Upper Jurassic (J3) top, of Cenomanian (Kcn) top, and of four main seismic horizons within the uppermost part of the Upper Jurassic interval located above the buildup deposits (1J3U, 2J3U, 3J3U, 4J3U). Main depositional systems are based on Gutowski et al. (2005) and Krzywiec et al. (2009).

erately hard platy-like limestones encountered at about 915 $935 \mathrm{~m}$. Similar to the Chopin-1 well, above the carbonate buildup complex the marly zone is present in the Belvedere1 well, comprising mainly marls and marly limestones about $25-35 \mathrm{~m}$ thick. The marly zone is lithologically diversified, which is clearly illustrated by the gamma ray log, as well as the sonic log (Fig. 7). Above the marly zone, a section comprises diverse oolitic-platy limestone deposits (about $50 \mathrm{~m}$ thick), which belongs to the uppermost part of the Upper Jurassic, and this interval is associated with the interpreted seismic-stratigraphic J3U unit (Fig. 7). Seismic horizons for both the marly zone and the J3U interval are influenced by intensive intra-bedded signal interference. This is possibly related to the presence of marl-limestone alternations.

\subsection{Interpretation of seismic data}

All the key seismic horizons (top Palaeozoic, top Triassic, top Middle Jurassic, top Jurassic, top Cenomanian) have been interpreted on legacy and new (SLE) seismic profiles. However, due to the lower seismic resolution of the legacy data, intra-Upper Jurassic seismic horizons associated with the J3U unit have been interpreted only using new SLE profiles.

The present-day structure of the study area is dominated by reverse faulting along the fault zones deeply rooted in the Palaeozoic and older basement (Figs. 8-10). Some of these faults might have been active in the Late Jurassic, but clearly their main phase of activity was associated with the Late Cretaceous-Paleogene regional inversion of the Polish Basin (cf. Scheck-Wenderoth et al., 2008; Krzywiec et al., 2009). 


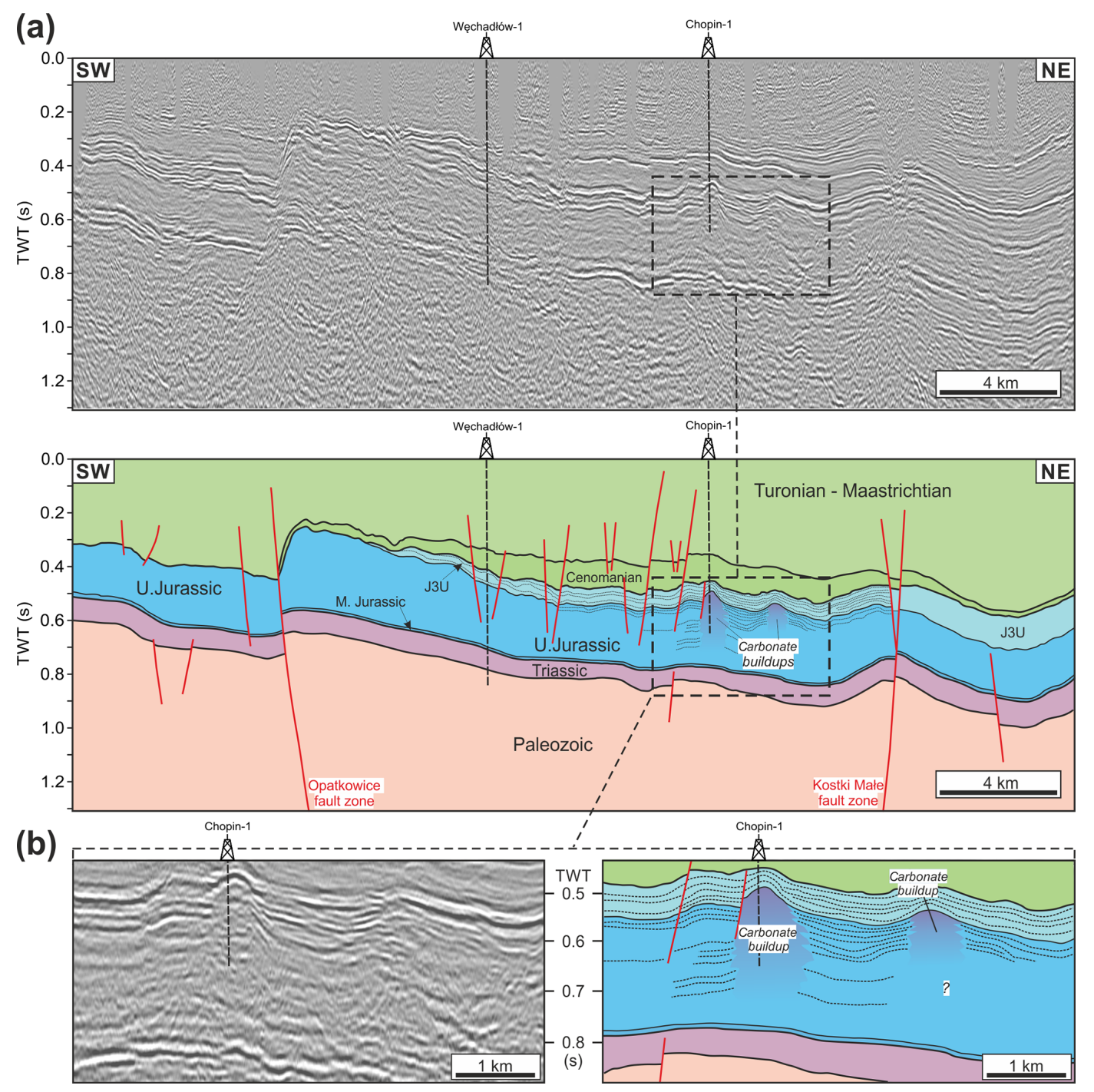

Figure 8. (a) Uninterpreted and interpreted seismic profile (12-5-92K) from the Miechów Trough (see Fig. 5 for location). Major NWSE-oriented Opatkowice and Kostki Małe fault zones are rooted in the Palaeozoic basement and are associated with inversion anticlines developed within the Mesozoic cover. (b) Two carbonate buildups were identified in this profile, one of which was partly drilled by the SLE Chopin-1 well.

Pre-Mesozoic (Precambrian to Carboniferous) rock complexes belong to the Małopolska Block (Żelaźniewicz et al., 2011). It is covered by the Triassic and Middle Jurassic deposits formed within the marginal part of the Polish Basin. The Upper Jurassic succession exhibits considerable lateral thickness changes caused by variable Late Jurassic local subsidence patterns (cf. Złonkiewicz, 2006) and later erosion. It gradually thickens towards the north-east, i.e. towards the Holy Cross Mountains, where the axial, most subsiding part of the Polish Basin, the Mid-Polish Trough, was located (Figs. 8-10). The Jurassic-Cretaceous boundary is related to a subtle angular unconformity or disconformity that truncates the Upper Jurassic strata. The Lower Cretaceous is not present in the study area. The fault-related fold- ing related to the inversion of this segment of the Polish Basin could be observed for the entire Upper Cretaceous (Cenomanian-Maastrichtian) succession and indicates the latest Cretaceous-Paleogene age of inversion.

The Upper Jurassic isolated carbonate buildups have been originally identified using legacy seismic profiles. Carbonate buildup drilled by the Chopin-1 well is characterized by the most significant positive relief (Fig. 8). Another organic buildup is located approximately $2 \mathrm{~km}$ towards the north-east (Fig. 8). Both these buildups are characterized by a mound-shaped reflection pattern, a drape effect above the structure and characteristic depositional wings associated with the buildup's edges. Another profile illustrates relatively smaller but more strongly expressed mound-shaped carbon- 

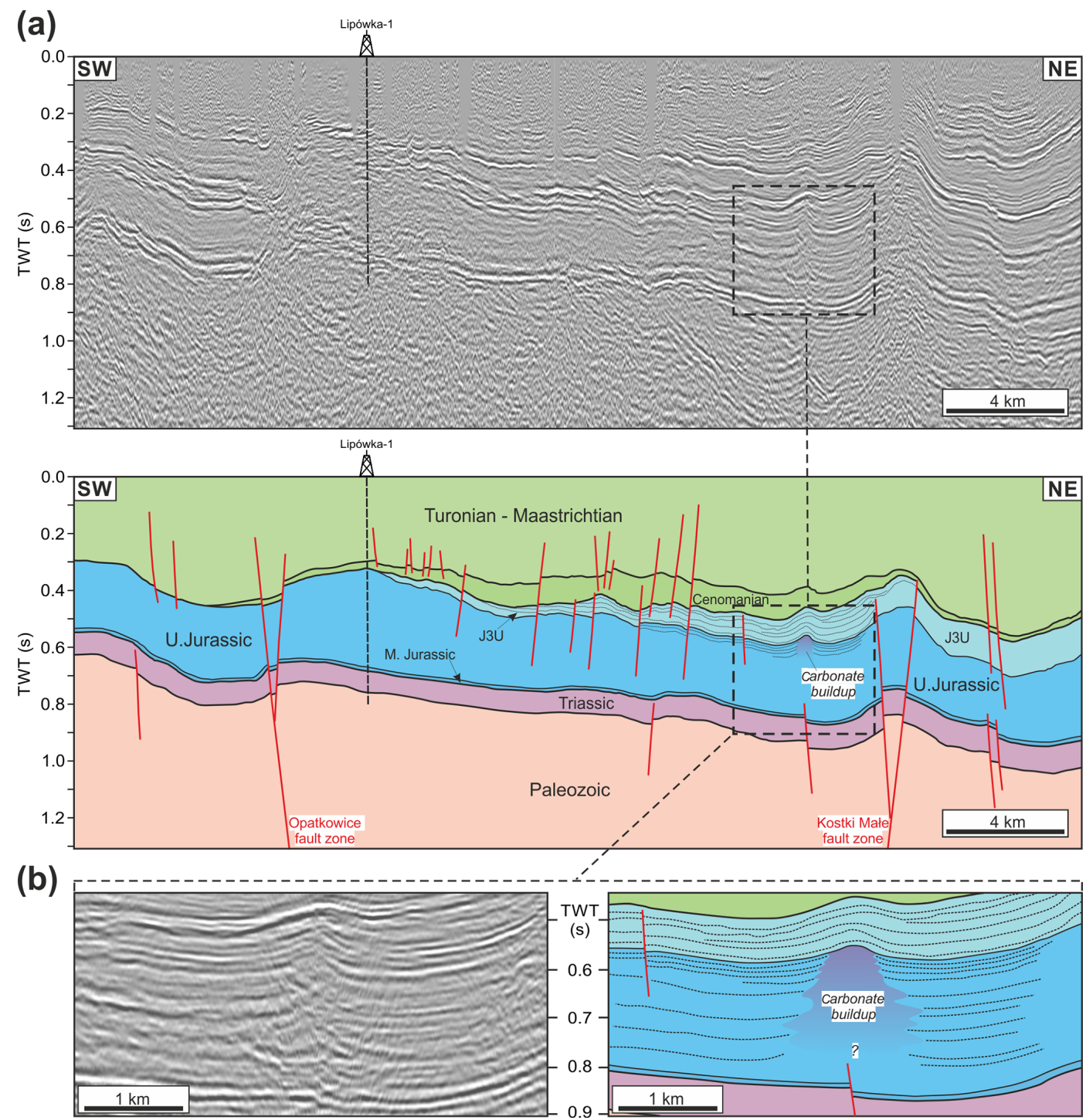

Figure 9. (a) Uninterpreted and interpreted seismic profile (11-5-92K) from the Miechów Trough (see Fig. 5 for location). Major NWSE-oriented Opatkowice and Kostki Małe fault zones are rooted in the Palaeozoic basement and are associated with inversion anticlines developed within the Mesozoic cover. (b) One isolated carbonate buildup was identified in this profile.

ate buildup (Fig. 9). A significant drape effect reaching up to the Cenomanian deposits could be observed above this buildup. Depositional wings are also clearly visible. Identification of the base of this structure is ambiguous. Other examples of the Upper Jurassic carbonate buildups identified in legacy data are shown in Fig. 10. One of those relatively small buildups is located in close vicinity to the Michałów-3 well.

Lateral seismic facies changes within the Upper Jurassic succession are clearly visible on all analysed seismic profiles. Mound-shaped seismic facies that represent carbonate buildups laterally pass into the parallel and continuous seismic reflections related to bedded carbonate deposits.
Much more detailed information on Upper Jurassic carbonate buildups was provided by new SLE seismic data (Figs. 11-15). Figure 11 shows the results of the detailed interpretation of one of these seismic profiles that was acquired directly above the large Upper Jurassic carbonate buildup which was drilled by the Chopin- 1 well. The carbonate buildup is characterized by chaotic, low-amplitude seismic reflections. The estimated lateral extent of this buildup is up to $1 \mathrm{~km}$. The thickness of the J3U interval is different on both sides of the buildup - it increases on its eastern side, where several onlapping horizons are visible. This might be related to local syn-depositional faulting within deeper substrata. The base of this buildup is not clearly imaged due 

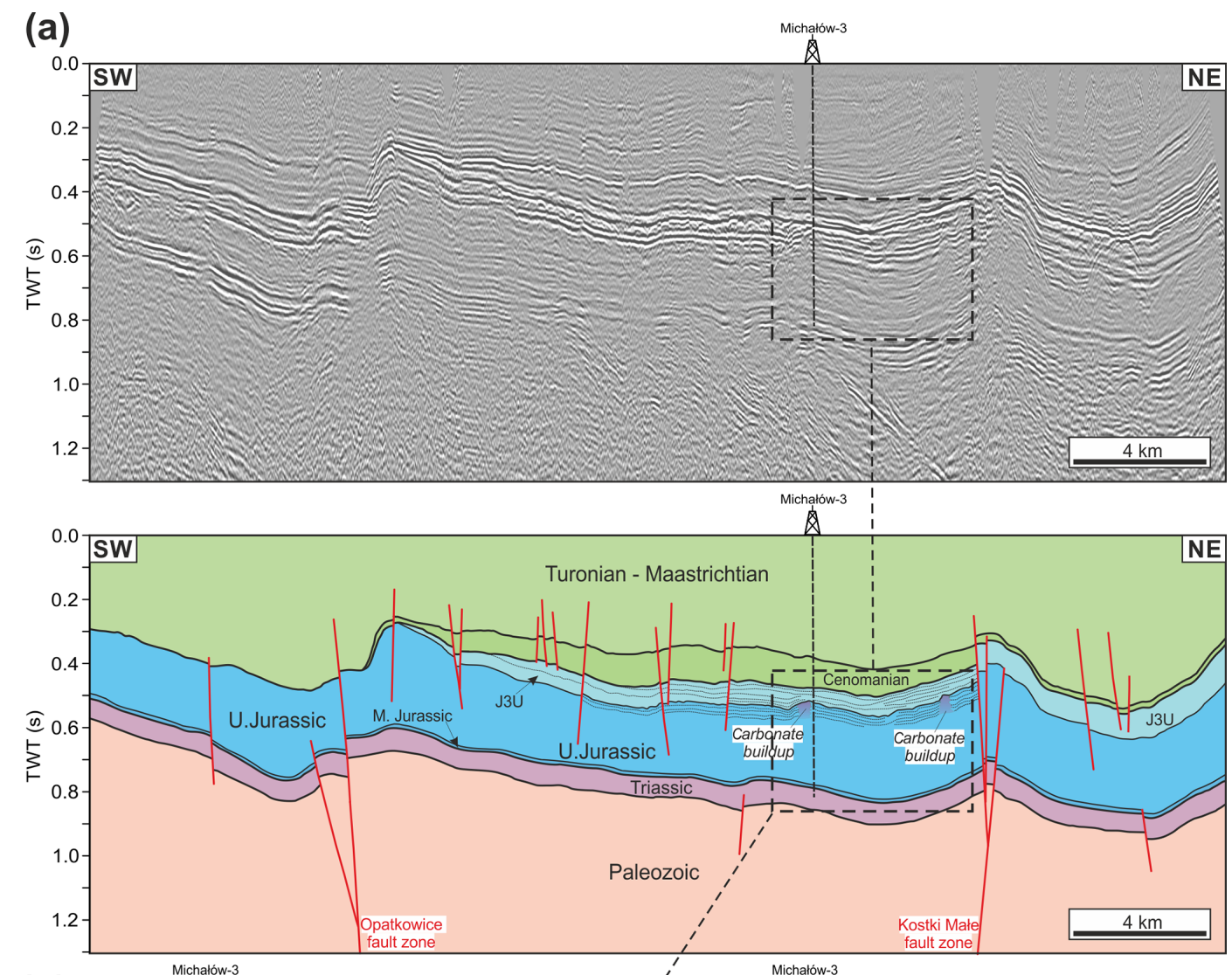

(b)

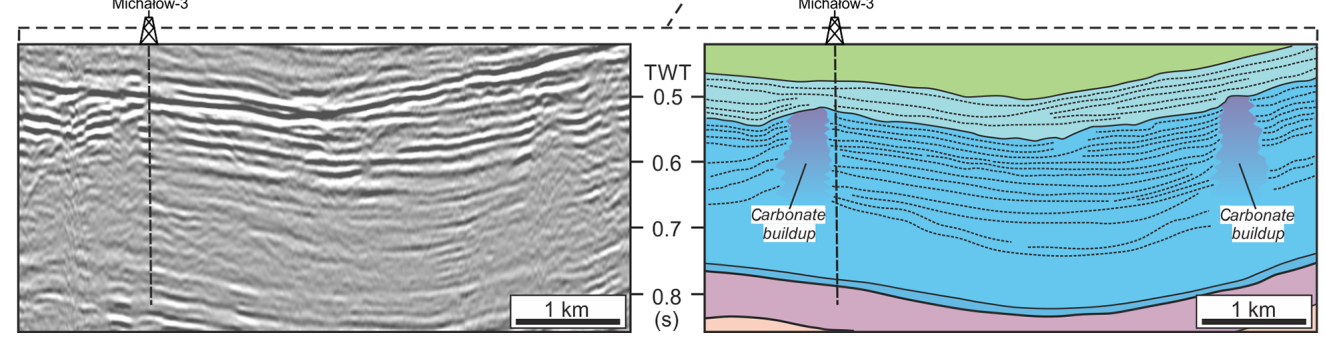

Figure 10. (a) Uninterpreted and interpreted seismic profile (10-5-92K) from the Miechów Trough (see Fig. 5 for location). Major NWSE-oriented Opatkowice and Kostki Małe fault zones are rooted in the Palaeozoic basement and are associated with inversion anticlines developed within the Mesozoic cover. (b) Two carbonate buildups were identified in this profile.

to (1) strong wavelet interference, (2) reflections from the buildup's edges and (3) limited seismic resolution.

Several small-scale faults have been interpreted on this seismic profile. Deeper faults that transect the PalaeozoicTriassic-Middle Jurassic interval might be partly related to older phases of tectonic evolution of the area. However, it should be stressed that seismic data in time domain might also suffer from local velocity effects such as velocity pullup beneath the massive - i.e. seismically fast - carbonates. Therefore, the interpreted geometry beneath the carbonate buildups should be treated with a certain degree of caution and not regarded as an exact representation of the sub-Upper Jurassic structure.

Upper Jurassic carbonate buildup drilled by the Belvedere1 well is shown in Fig. 12. This structure does not exhibit such strong positive relief as the buildup shown in Fig. 11, and its outline is less visible. This carbonate buildup consists of two massive limestone successions separated by platy-like limestone strata (Fig. 7), and this might be one of the reasons for less clear seismic imaging. The western edge of this carbonate buildup is transected by a normal fault, across which a slight thickness increase in the J3U unit is observed, suggesting syn-depositional activity.

The highest amplitudes and the most continuous seismic horizons are observed for the J3U unit (Figs. 11 and 12). This might be related to sharp lithological contrasts within this interval caused by the occurrence of limestones interbedded by marls and marly limestones of the marly zone (cf. Figs. 6 and 7). Sub-horizontal seismic horizons, associated with bed- 

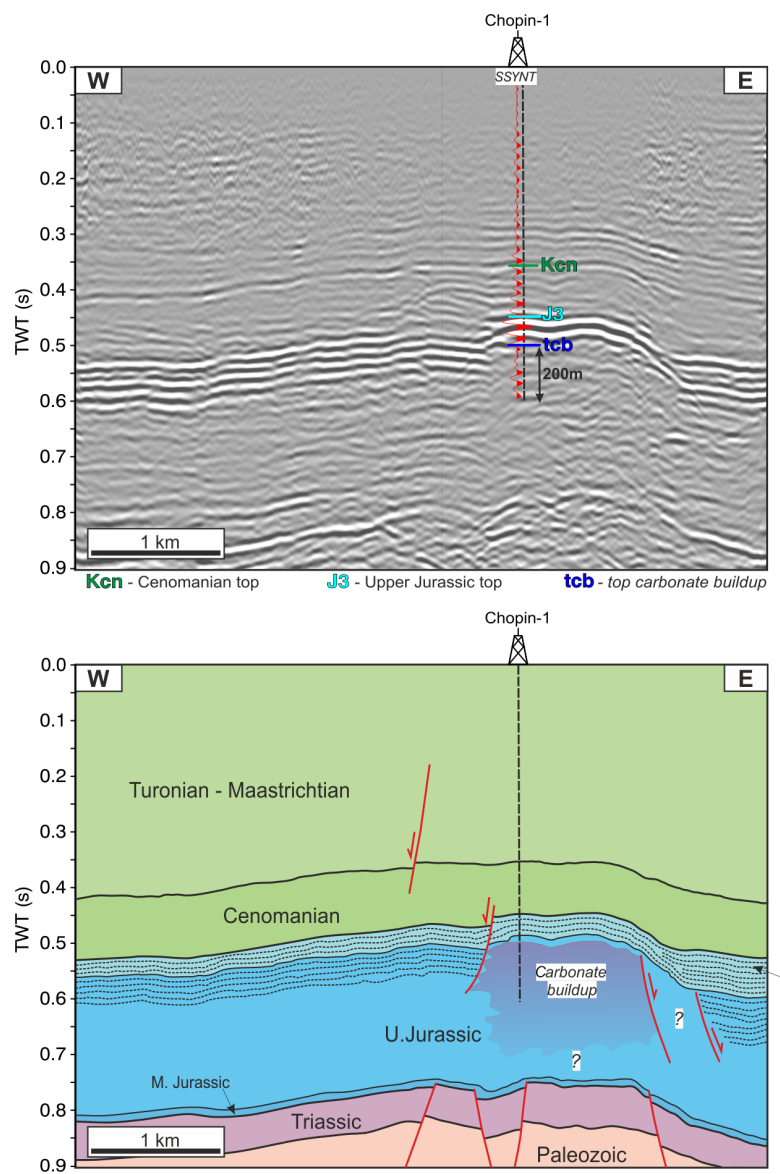

J3U

Figure 11. Uninterpreted and interpreted seismic profile across the carbonate buildup complex (see Fig. 5 for location). This carbonate buildup was partly drilled by the Chopin-1 well. Well tops, the interpreted top of the carbonate buildup (tcb) and the synthetic seismogram (SSYNT) are shown (see Fig. 6 for details).

ded carbonates surrounding the carbonate buildups, are also clearly visible (Figs. 11 and 12).

Finally, important differential compaction and related compaction sag effects could be observed above all the identified carbonate buildups. Carbonate buildups, generally represented by rigid, massive limestones, are more resistant to compaction, while the surrounding bedded carbonate facies are much more prone to compaction. This effect can be very clearly seen on the seismic profile shown in Fig. 13. It is expressed by (1) the drape effect above the buildup, which is evidence of lower compaction (typical for resistant carbonate buildup deposits), and (2) compaction sag as evidence of higher compaction, which is typical for bedded carbonates surrounding buildups. This seismic pattern could be observed for the Upper Jurassic succession and, although to a lesser degree, also within the lowermost part of the Upper Cretaceous succession. Differential compaction may have also led to the formation of some of the normal faults along the borders of the carbonate buildups (Figs. 11 and 13).
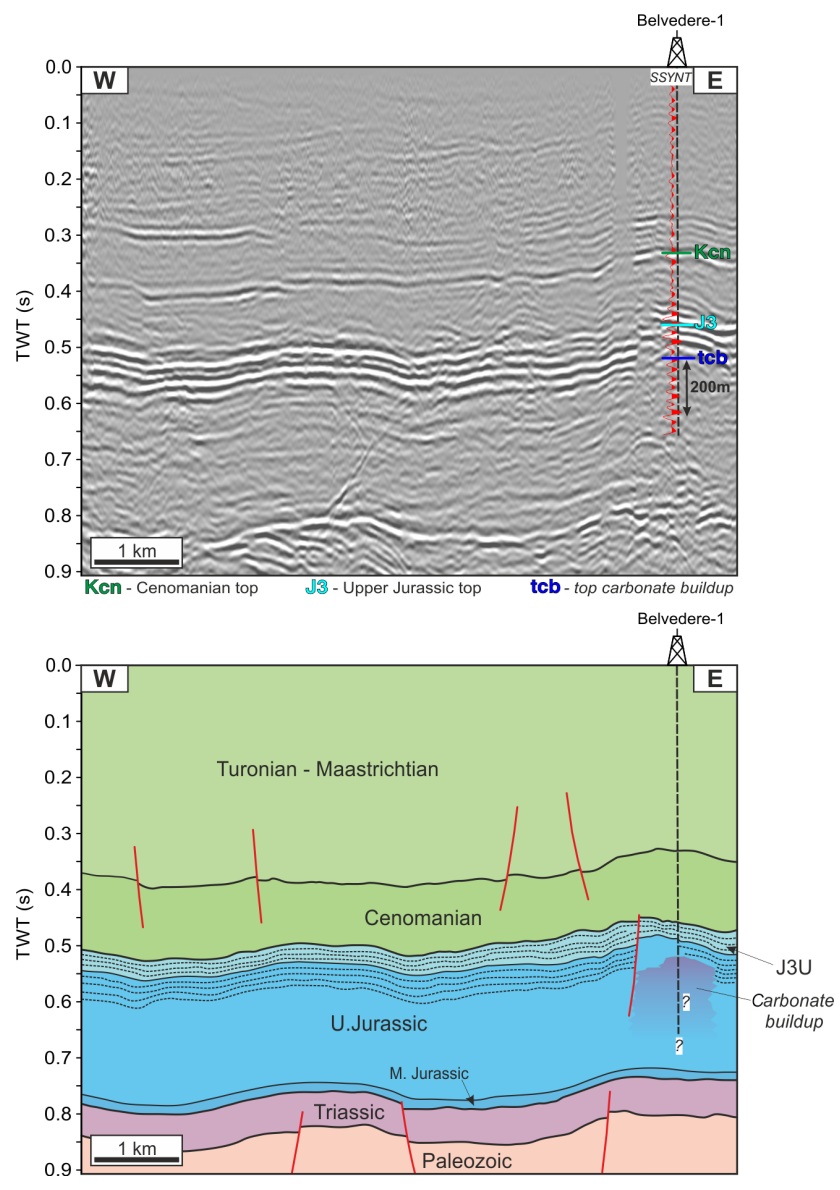

Figure 12. Uninterpreted and interpreted seismic profile across the carbonate buildup complex (see Fig. 5 for location). This carbonate buildup was partly drilled by the Belvedere-1 well. Well tops, the interpreted top of the carbonate buildup (tcb) and the synthetic seismogram (SSYNT) are shown (see Fig. 7 for details).

The velocity pull-up effect observed beneath the carbonate buildups (cf. Fig. 13) results from lateral seismic velocity contracts between the massive and stratified (bedded) carbonates. The interval velocity of the massive limestones, drilled by modern Chopin- 1 and Belvedere- 1 wells, is about $5000-5500 \mathrm{~m} \mathrm{~s}^{-1}$, which is significantly higher in comparison to the seismic velocity obtained from the Michałów-3 and Lipówka-1 legacy wells for the corresponding stratified deposits, which is in the order of ca. $3800-5000 \mathrm{~m} \mathrm{~s}^{-1}$. However, it should be taken into account that velocity information from these old wells should be treated only tentatively due to their uncertainty resulting from the lower quality of older well $\log$ data. Expected lateral seismic velocity variations between the massive and bedded carbonates often exceed $10 \%$ and might be responsible for producing some velocity pullups beneath the seismically faster carbonate buildups. Thus, it is probable that, at least for some of the morphological heights situated beneath the carbonate buildups in the time seismic data analysed, velocity pull-ups might have distorted 

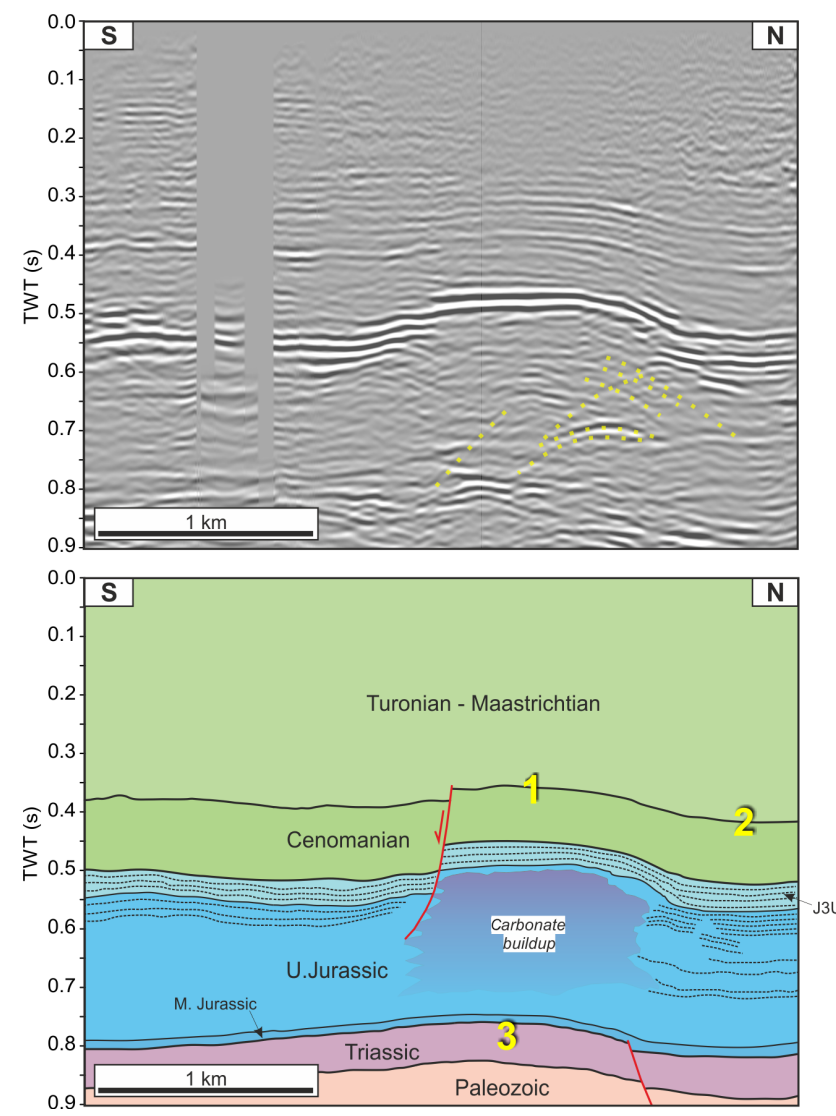

Figure 13. Uninterpreted and interpreted seismic profile across the carbonate buildup complex (see Fig. 5 for location). The effect of differential compaction between the carbonate sediments (generally much higher for bedded carbonate facies, very low for massive limestones) can be clearly seen. Usually, these effects could also be visible within the younger, Upper Cretaceous overburden. As a result, the younger strata also partly exhibit drape reflections (1) and compaction sag effects (2). Other characteristic seismic indicators can be also observed, i.e. the velocity pull-up effect for horizons below the buildup's base (3) and the diffraction on the buildup's edges (dotted yellow lines marked on the uninterpreted profile). Differential compaction may have also led to the formation of normal faults along the borders of carbonate buildup.

their true geometries. The similar role of high-velocity reefal intervals in the production of velocity pull-up effects beneath the carbonate buildups was described for time seismic data characterizing the large Miocene buildups in Luconia, Malaysia (e.g. Zampetti et al., 2004; Rankey et al., 2019), or numerous isolated buildups in the north-western shelf of Australia (Saquab and Bourget, 2016).

The lateral extent of the carbonate buildups identified using seismic data from the central part of the Miechów Trough is in the range of 400-1000 m, and the present-day total height of most structures is around $150-200 \mathrm{~m}$. Yet, the present-day cumulative height of the two largest complexes observed, drilled by the Chopin-1 and Belvedere-1 wells, probably exceeds $250 \mathrm{~m}$. However, identification of the base of the buildups was ambiguous due to rather poor seismic imaging of the lowermost part of the large buildup complexes (Figs. 11 and 12). Both structures are hundreds of metres long (even up to $1 \mathrm{~km}$; Figs. 11-13).

\section{Discussion}

\subsection{Carbonate buildups in seismic data - regional context}

Results presented in this paper illustrate how and to what extent seismic data can be used for the analysis of carbonate depositional systems and in particular for the identification of the carbonate buildups and the enveloping strata. In this study, several large Upper Jurassic carbonate buildups in the Miechów Trough (southern Poland) have been seismically identified and characterized. Possible occurrences of carbonate buildups in the study area has already been tentatively proposed by several authors (cf. Gutowski et al., 2005; Matyja, 2009; Złonkiewicz, 2009). However, so far no direct evidence of their presence in this part of the basin has been presented. In southern Poland, where the Upper Jurassic strata are covered by thick Cretaceous and younger deposits, such as in the Miechów Trough, previous studies of these deposits were carried out using information from older research wells only (cf. Złonkiewicz, 2006, 2009). The availability of deep wells in this part of the basin, including the study area, is, however, insufficient for detailed analysis of the geometry and architecture of the carbonate depositional system - in particular for the identification of the carbonate buildups. In comparison to adjacent areas in Poland and central and western Europe, where the Upper Jurassic is well-known from outcrops (cf. Leinfelder et al., 1996; Matyszkiewicz, 1997a), a carbonate succession in the Miechów Trough until recently remained much less recognized. Seismic data described in this paper allowed for the identification of large carbonate buildups and the surrounding enveloping strata and therefore provided new crucial information on the Late Jurassic depositional system in this part of the basin. Results of this study could also be used as a more universal reference point for seismic studies of carbonate depositional systems of different ages from different sedimentary basins.

The seismically interpreted carbonate buildups from the study area formed part of the vast Late Jurassic carbonate depositional system that developed along the northern, passive shelf of the Tethys, forming in Europe a belt extending from Portugal through Spain, France, southern Germany, and Poland to Ukraine and Romania (Leinfelder et al., 1996). The quality of the presented seismic examples is quite unique in comparison to a few other papers dealing with the seismic interpretation of Upper Jurassic carbonate buildups in central and western Europe. In comparison to the Upper Jurassic carbonate buildups seismically recognized in southern Ger- 
many (cf. Hartmann et al., 2012; Lüschen et al., 2014; see Fig. 2), buildups described in this paper are much better imaged in seismic data. The present-day observed cumulative heights of carbonate buildups from the Miechów Trough are distinctly larger than in the seismically described reefs from the Bavarian Molasse Basin, for which a total thickness of the reef succession does not exceed $180 \mathrm{~m}$ (Hartmann et al., 2012). This confirms that carbonate sedimentation in the Polish part of the northern Tethyan shelf was more intense than in southern Germany (cf. Matyja and Wierzbowski, 1996). The observed vertical size of the carbonate buildups described in this study is similar to the Upper Jurassic reefs recognized in seismic data from the western Caucasus and Black Sea regions (Afanasenkov et al., 2007; Guo et al., 2011). This suggests that in both areas the local depositional environments (including palaeo-bathymetry and subsidence) were at least generally similar.

The Upper Jurassic carbonate buildups also have been recognized using seismic data in Poland 40-60 km south of the study area within the southern segment of the Miechów Trough that is covered by Miocene sediments of the Carpathian Foredeep Basin (Misiarz, 2003; Gliniak and Urbaniec, 2005; Gliniak et al., 2005; JędrzejowskaTyczkowska et al., 2006). The vertical and lateral size of those structures is generally comparable to the size of carbonate buildups described in this paper. This suggests that the growth of all these structures took place in a relatively unified depositional environment that characterized this part of the basin. Recently, Urbaniec (2019) provided seismic examples of Upper Jurassic carbonate buildups of a similar size that are located about $50 \mathrm{~km}$ south-east of the study area. Those buildups are characterized by complex geometries and probably consist of several levels of the massive limestones.

The results of the seismic interpretation of carbonate buildups presented also have more universal applications. They can be used as a reference point for the analysis of carbonate buildups and elements of the depositional system using seismic data from other sedimentary basins. The quality of the seismic image is comparable to some case studies of this type from various areas in the world (cf. Elvebakk et al., 2002; Zampetti et al., 2004).

\subsection{Geometry and depositional architecture of the Upper Jurassic basin}

The depositional architecture of the Upper Jurassic carbonate succession in the study area recognized in seismic data (Figs. 11-15) resembles a classic carbonate system wellknown from outcrops located within the adjacent KrakówCzęstochowa Upland (Figs. 3 and 4a). It is characterized by the presence of carbonate buildup complexes surrounded by diverse bedded carbonate facies (Dżułyński, 1952; Matyja and Wierzbowski, 1996, 2006; Matyszkiewicz et al., 2012; Krajewski et al., 2018). The Upper Jurassic succession in the Kraków-Częstochowa Upland (Figs. 3 and 4a) is charac- terized by strong local vertical and lateral thickness and facies variability. This is mainly related to differentiated relief at the top of the Palaeozoic substratum which is associated with local differentiation in subsidence caused by the occurrence of Permian intrusions, syn-sedimentary tectonics and the local, mostly aggradational growth of organic buildups, as well as differential compaction of carbonate sediments (Matyszkiewicz, 1999; Matyszkiewicz et al., 2006, 2012, 2016; Kochman and Matyszkiewicz, 2013; Matyszkiewicz and Kochman, 2016). The Upper Jurassic succession in the Kraków-Częstochowa Upland consists of (1) bedded facies, (2) massive facies and (3) deposits of gravity flows (Matyszkiewicz et al., 2012). Massive and bedded limestone facies belong to the sponge megafacies deposits (Matyja and Wierzbowski, 2006). This succession, characterized by the abundant presence of siliceous sponges and microbial structures, is common within the northern Tethyan shelf margin of central and western Europe in the Late Jurassic (e.g. Matyja and Pisera, 1991; Matyja and Wierzbowski, 1995, 2006; Wierzbowski et al., 2016; see Fig. 2). In the KrakówCzęstochowa Upland, massive limestones constitute large carbonate buildup complexes that are surrounded by bedded limestones and marls which were formed within intrabuildup sub-basins or much wider (up to several kilometres long) inter-buildup basins (cf. Matyja and Wierzbowski, 1996). Massive facies (carbonate buildups) pass laterally into bedded facies (Gutowski et al., 2005, 2006; Matyja and Wierzbowski, 2006; see Fig. 4a). Similar elements of depositional architecture can be observed in seismic data from the study area (Figs. 14 and 15). Mound-shaped seismic facies that represent carbonate buildups laterally pass into the parallel and continuous seismic reflections related to bedded carbonate deposits which represent intra-buildup sub-basins (Figs. 14 and 15). Present-day cumulative heights (150$250 \mathrm{~m})$ and lateral extents $(400-1000 \mathrm{~m})$ of the structures identified in seismic data from the Miechów Trough are generally comparable with large carbonate buildup complexes known from the Kraków-Częstochowa Upland (cf. Matyja and Wierzbowski, 1996, 2006; Matyszkiewicz et al., 2006, 2012, 2015b).

The examples presented strongly suggest that (1) similar basin geometries (e.g. carbonate buildups, intra-buildup sub-basins) and (2) main facies relationships (i.e. massive facies versus bedded facies) for the Upper Jurassic succession could be reliably distinguished in seismic data from the study area. Seismic images of bedded facies revealed significant vertical lithological variations which are expressed by high-amplitude continuous seismic reflections (see Figs. 14 and 15). This might be related to strong vertical lithological variability known from equivalent deposits in the KrakówCzęstochowa Upland, where the bedded facies commonly include marls and marl-limestone alternations which are several metres thick (e.g. Matyja and Wierzbowski, 2006; Matyszkiewicz, 2008). Such distinct lithological contrasts (bedded limestones alternated by marls) are probably re- 

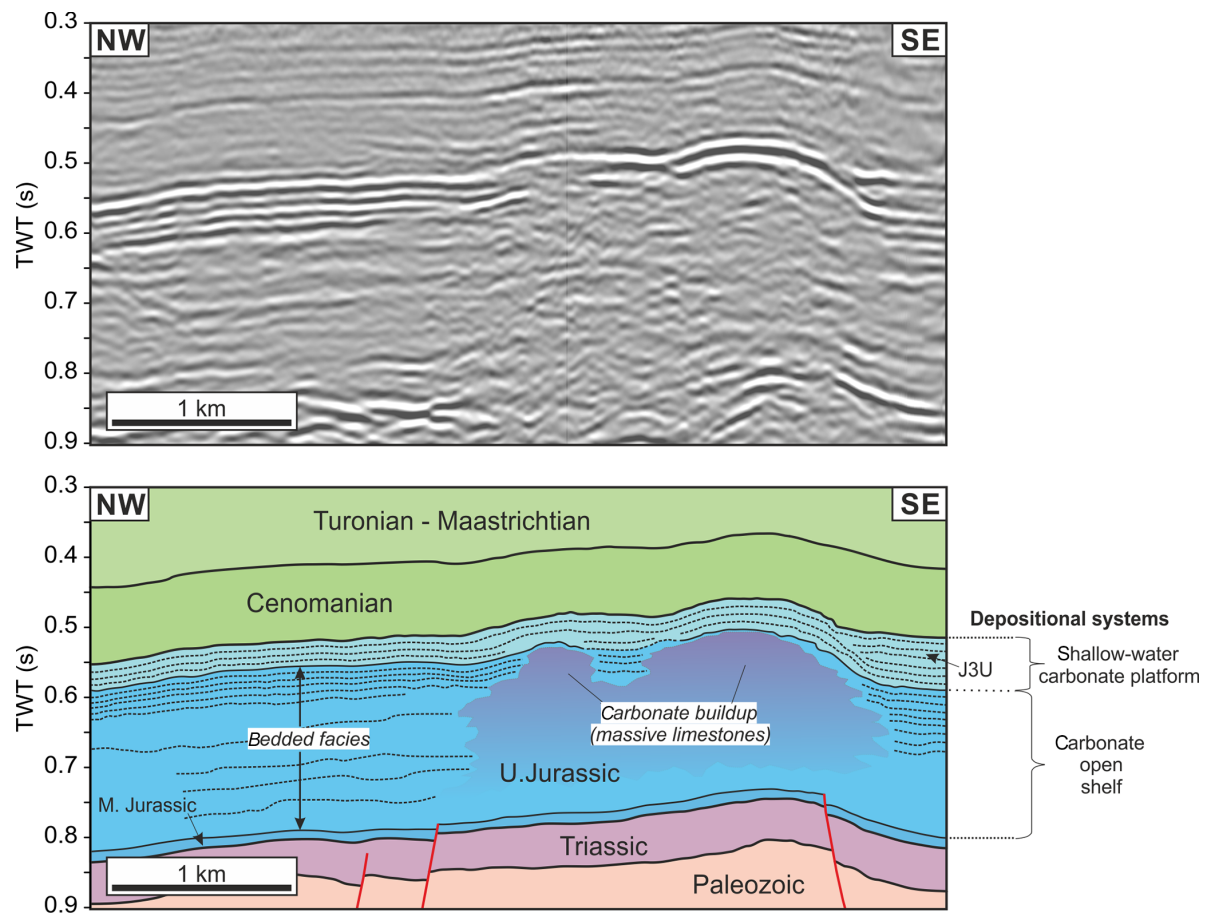

Figure 14. Uninterpreted and interpreted seismic profile across the carbonate buildup complex (see Fig. 5 for location). Lateral seismic facies changes correspond to main facies changes within the Upper Jurassic: bedded facies (represented by diverse bedded limestones and marls) to massive limestones (carbonate buildups).
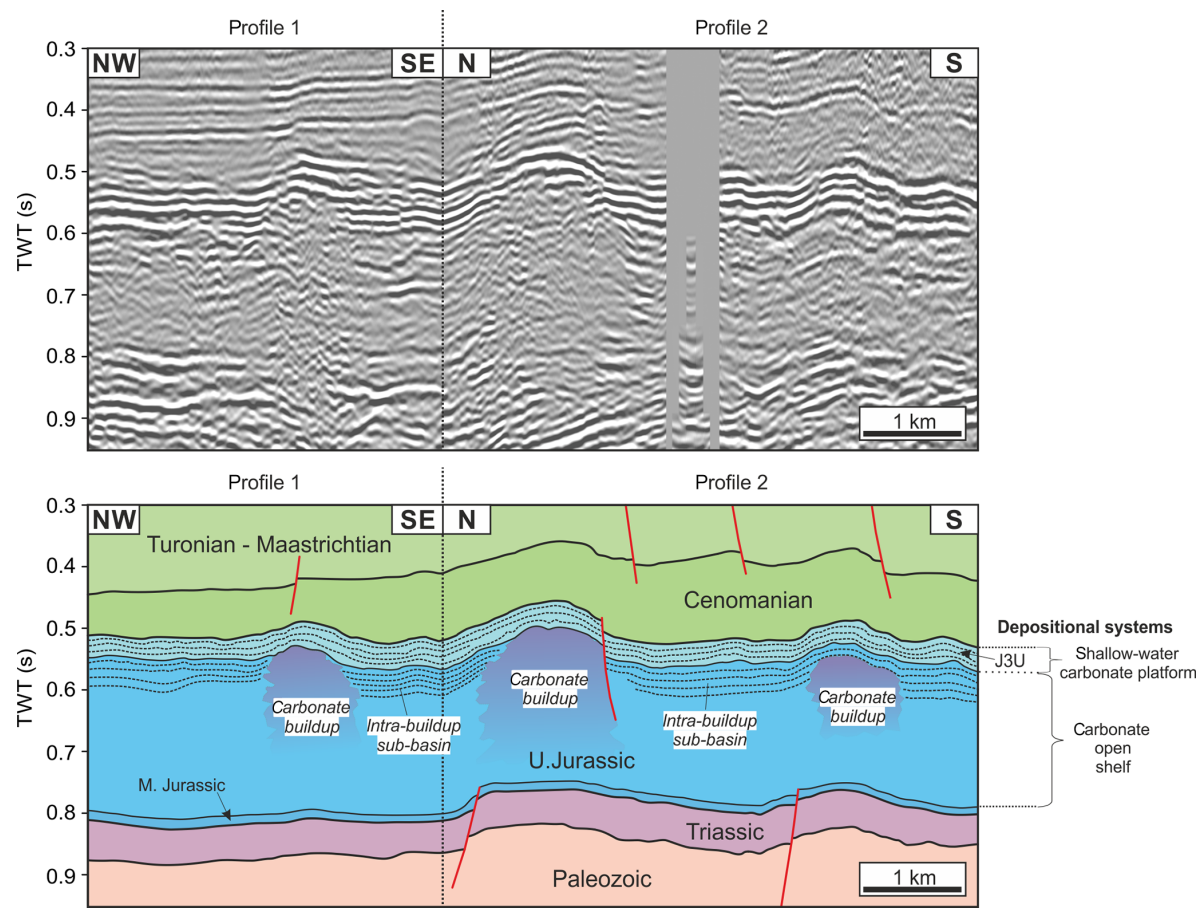

Figure 15. Uninterpreted and interpreted seismic transect (see Fig. 5 for location) showing distinctive elements of depositional architecture of the Upper Jurassic succession in the study area: presence of large carbonate buildup complexes represented by massive facies, and intrabuildup sub-basins represented by bedded facies. 
sponsible for producing these characteristically strong, subhorizontal seismic horizons (compare with Figs. 14 and 15).

The results of the seismic interpretation could be correlated with the main Upper Jurassic lithofacies scheme proposed by Złonkiewicz (2009) for the entire Miechów Trough (see Fig. 4b). The uppermost part of the Upper Jurassic interval, which corresponds with the J3U seismic-stratigraphic unit characterized by high-amplitude flat seismic horizons (Figs. 6-7 and 14-15), can be related to the shallow-water carbonate platform, represented predominantly by ooliticplaty deposits comprised mainly of limestones, marly limestones and marls (Złonkiewicz, 2009; cf. Kutek, 1968; Matyja et al., 1989, 2006; Gutowski et al., 2005, 2006; Krajewski et al., 2017; see Fig. 4b). Massive limestones, which represent carbonate buildups, might be related to the massive limestone member, and the bedded facies could refer to the heterogeneous Siedlce limestone member (Matyja, 1977; Złonkiewicz, 2009; see Figs. 4b and 14). The lower part of the Upper Jurassic interval may also be partly associated with the Morawica limestone member and the lowermost marlydominated strata (Złonkiewicz, 2009; see Fig. 4b).

Above the top of large carbonate buildups (Figs. 11 and 12), the higher gamma ray log values clearly indicate the presence of marly and marly limestone deposits which are related to the marly zone interpreted from the 1D seismic stratigraphic analysis (see Figs. 6 and 7). This interval might be associated with the disappearance of the organic buildups and a change in sedimentary conditions related to the drowning of the carbonate ramp, which is evident from the deposition of deeper-water marly facies (cf. Krajewski et al., 2017; see also Kutek, 1968, 1994).

\section{Conclusions}

This paper provides new, important information on Late Jurassic sedimentation in the Miechów Trough that was located within the transition zone between the epicontinental basin of central and western Europe and the Tethys Ocean. This area has been hitherto less recognized in comparison to adjacent areas in Poland and central and western Europe, where the Upper Jurassic deposits are well-known from outcrops. The results of seismic data interpretation of the study area proved the presence of large carbonate buildups in this part of the Upper Jurassic basin in southern Poland. The carbonate buildups identified exhibit significant positive relief; the lateral extent of particular complexes is in the range of 400-1000 $\mathrm{m}$, and the observed cumulative height of most structures is in the range of $150-250 \mathrm{~m}$. This study revealed the distinctive depositional architecture of the carbonate Upper Jurassic succession. The mound-shaped seismic facies that represent large carbonate buildups laterally pass into the parallel and continuous seismic reflections related to the well-bedded basinal deposits (limestones and marls) that were formed within the intra-buildup sub-basins or wider inter-buildup basins. The geometry and architecture of the Upper Jurassic basin in the Miechów Trough resemble the well-recognized open-shelf carbonate depositional system of the adjacent Kraków-Częstochowa Upland. Seismic unit J3U that overlies the open-shelf deposits represents younger, shallow-water carbonate platform succession. Between the J3U unit and the top of the carbonate buildups, the distinctive marly zone has been interpreted from the 1D seismicstratigraphic analysis and the gamma ray logs. This interval is represented by deeper-water facies that might be related to the carbonate platform drowning and demise of the organic buildups. The results shown in this paper fill the gap in the recognition of the Late Jurassic palaeogeography of southern Poland and provide well-documented examples of a system of carbonate buildups developed in the south-eastern segment of the transition zone between the European Late Jurassic epicontinental basin and the Tethys Ocean.

Data availability. The data presented in this study have been provided by an oil company and are not publicly accessible.

Author contributions. ŁS carried out the seismic interpretation and prepared the paper. PK participated in the analysis and discussion of the final results and supervised the preparation of the paper.

Competing interests. The authors declare that they have no conflict of interest.

Acknowledgements. We thank San Leon Energy and PGNiG S.A. for granting us access to the seismic and well data used in this study. IHS Markit kindly provided Kingdom seismic interpretation software. Łukasz Słonka would like to thank Andrzej Wierzbowski (PGI, Warsaw), Jacek Matyszkiewicz (AGH UST, Kraków) and Marcin Krajewski (AGH UST, Kraków) for their literature recommendations and for constructive comments on the early results of this study, as well as Joachim Szulc (deceased), Anna Lewandowska and Wojciech Wróblewski (all from Jagiellonian University, Kraków) for their help during the fieldwork. Many thanks are due to Aleksandra Stachowska for her help in collecting materials and helpful comments on the final version of the paper and to Ashley Gumsley for correcting the English. Comments and suggestions from reviewers Jacek Matyszkiewicz, Tadeusz Peryt and Gabor Tari greatly helped in finally refining this paper and are highly appreciated.

Review statement. This paper was edited by Elias Samankassou and reviewed by Tadeusz Peryt, Jacek Matyszkiewicz and Gabor Tari. 


\section{References}

Adámek, J.: The Jurassic floor of the Bohemian Massif in Moravia geology and paleogeography, Bull. Geosci., 80, 291-305, 2005.

Afanasenkov, A. P., Nikishin, A. M., and Obukhov, A. N.: Geology of the Eastern Black Sea, Scientific World, Moscow, 72 pp., 2007.

Bachtel, S. L., Dunn, P. A., Rahardjanto, S. P., Kissling, R. D., Martono, D., and MacDonald, B. A.: Seismic stratigraphic evolution of the Miocene-Pliocene Segitiga Platform, East Natuna Sea, Indonesia: The origin, growth, and demise of an isolated carbonate platform, in: Seismic imaging of carbonate reservoirs and systems, edited by: Eberli, G. P., Massaferro, J. L., and Sarg, J. F., AAPG Memoir, 81, 309-328, https://doi.org/10.1306/M81928, 2004.

Barski, M. and Matyja, B. A.: Stratygrafia górnej jury podłoża zapadliska przedkarpackiego w oparciu o mikroskamieniałości, Kwartalnik AGH Geologia, 34, 163-164, 2008.

Belopolsky, A. V. and Droxler, A. W.: Seismic expressions of prograding carbonate bank margins: Middle Miocene, Maldives, Indian Ocean, in: Seismic imaging of carbonate reservoirs and systems, edited by: Eberli, G. P., Massaferro, J. L., and Sarg, J. F., AAPG Memoir, 81, 267-290, https://doi.org/10.1306/M81928, 2004.

Blendinger, W., Bowlin, B., Zijp, F. R., Darke, G., and Ekroll, M.: Carbonate buildup flank deposits: an example from the Permian (Barents Sea, northern Norway) challenges classical facies models, Sediment. Geol., 112, 89-103, https://doi.org/10.1016/S0037-0738(97)00025-0, 1997.

Borgomano, J. R. F. and Peters, J. M.: Outcrop and seismic expressions of coral reefs, carbonate platforms, and adjacent deposits in the Tertiary of the Salalah Basin, South Oman, in: Seismic imaging of carbonate reservoirs and systems, edited by: Eberli, G. P., Massaferro, J. L., and Sarg, J. F., AAPG Memoir, 81, 251-266, https://doi.org/10.1306/M81928, 2004.

Bubb, J. N. and Hatlelid, W. G.: Seismic Stratigraphy and Global Changes of Sea Level, Part 10: Seismic Recognition of Carbonate Buildups, in: Seismic Stratigraphy - Applications to Hydrocarbon Exploration, edited by: Payton, C. E., AAPG Memoir, 26, 185-204, 1977.

Buness, H., Hartmann, H., Rumpel, H. M., Beilecke, T., Musmann, P., and Schulz, R.: Seismic Exploration of Deep Hydrogeothermal Reservoirs in Germany, in: Expanded Abstracts, World Geothermal Congress, Bali, Indonesia, 2010.

Burgess, P. M., Winefield, P., Minzoni, M., and Elders, C.: Methods for identification of isolated carbonate buildups from seismic reflection data, AAPG Bull., 97, 1071-1098, https://doi.org/10.1306/12051212011, 2013.

Chang, J., Hsu, H., Liu, C., Lee, T., Chiu, S., Su, C., Ma, Y., Chiu, Y., Hung, H., Lin, Y., and Chiu, C.: Seismic sequence stratigraphic analysis of the carbonate platform, north offshore Taiping Island, Dangerous Grounds, South China Sea. Tectonophysics, 702, 70-81, https://doi.org/10.1016/j.tecto.2015.12.010, 2017.

Colpaert, A., Pickard, N., Mienert, J., Henriksen, L. B., Rafaelsen, B., and Andreassen, K.: 3D seismic analysis of an Upper Palaeozoic carbonate succession of the Eastern Finnmark Platform area, Norwegian Barents Sea, Sediment. Geol., 197, 79-98, https://doi.org/10.1016/j.sedgeo.2006.09.001, 2007.
Dadlez, R., Narkiewicz, M., Stephenson, R. A., Visser, M. T. M., and Van Wees, J. D.: Tectonic evolution of the Mid-Polish Trough: modelling implications and significance for central European geology, Tectonophysics, 252, 179-195, https://doi.org/10.1016/0040-1951(95)00104-2, 1995.

Dadlez, R., Marek, S., and Pokorski, J. (Eds.): Paleogeographical Atlas of Epicontinental Permian and Mesozoic in Poland (1 : 2500 000), Polish Geological Institute, Warszawa, 1998.

Dadlez, R., Marek, S., and Pokorski, J. (Eds.): Geological Map of Poland without Cainozoic Deposits (1 : 1000000), Polish Geological Institute, Warszawa, 2000.

Di Lucia, M., Sayago, J., Frijia, G., Cotti, A., Sitta, A., and Mutti, M.: Facies and seismic analysis of the Late Carboniferous Early Permian Finnmark carbonate platform (southern Norwegian Barents Sea): An assessment of the carbonate factories and depositional geometries, Mar. Petrol. Geol., 79, 372-393, https://doi.org/10.1016/j.marpetgeo.2016.10.029, 2017.

Dudek, D. and Wójcik, A.: Daily report: well Belvedere-1, unpublished technical report, PNiG Jasło Sp. z o.o, 2011.

Dudek, D., Wójcik, A., Gała, J., and Jacek, M.: Geological Log: well Belvedere-1, unpublished technical report, NAFTGAZ Wołomin, 2011.

Dżułyński, S.: The Origin of the Upper Jurassic Limestones in the Cracow Area, Rocznik Polskiego Towarzystwa Geologicznego, 21, 125-180, 1952.

Eberli, G. P., Anselmetti, F. S., Betzler, C., Van Konijnenburg, J. H., and Bernoulli, D.: Carbonate platform to basin transitions on seismic data and in outcrops: Great Bahama Bank and the Maiella Platform margin, Italy, in: Seismic imaging of carbonate reservoirs and systems, edited by: Eberli, G. P., Massaferro, J. L., and Sarg, J. F., AAPG Memoir, 81, 207-250, https://doi.org/10.1306/M81928, 2004.

Ellis, P. M., Wilson, R. C., and Leinfelder, R. R.: Controls on Upper Jurassic carbonate buildup development in the Lusitanian Basin, Portugal, in: Carbonate Platforms: Facies, Sequences and Evolution, edited by: Tucker, M. E., Wilson, J. L., Crevello, P. D., and Sarg, J. R., Spec. Publ. Int. Assoc. Sedimentolog., 9, 169-202, https://doi.org/10.1002/9781444303834.ch7, 1990.

Elvebakk, G., Hunt, D. W., and Stemmerik, L.: From isolated buildups to buildup mosaics: 3D seismic sheds new light on upper Carboniferous-Permian fault controlled carbonate buildups, Norwegian Barents Sea, Sediment. Geol., 152, 7-17, https://doi.org/10.1016/S0037-0738(02)00232-4, 2002.

Epting, M.: The Miocene carbonate buildups, central Luconia, offshore Sarawak, in: Atlas of seismic stratigraphy, edited by: Bally, A. W., AAPG Stud. Geol., 27, 168-173, 1989.

Feldman-Olszewska, A.: Depositional systems and cyclicity in the intracratonic Early Jurassic basin in Poland, Geol. Q., 41, 475489, 1997a.

Feldman-Olszewska, A.: Depositional architecture of the Polish epicontinental Middle Jurassic basin, Geol. Q., 41 491-508, 1997b.

Fontaine, J. M., Cussey, R., Lacaze J., Lanaud, R,. and Yapaudjian, L.: Seismic interpretation of carbonate depositional environments, AAPG Bull., 71, 281-297, https://doi.org/10.1306/94886E7F-1704-11D78645000102C1865D, 1987.

Fournier, F. and Borgomano, J.: Geological significance of seismic reflections and imaging of the reservoir architecture in the 
Malampaya gas field (Philippines), AAPG Bull., 91, 235-258, https://doi.org/10.1306/10160606043, 2007.

Fournier, F., Montaggioni, L. F., and Borgomano, J.: Paleoenvironments and high-frequency cyclicity in the Cenozoic south-east Asian shallow-water carbonates: A case study from the Oligo-Miocene buildups of Malampaya (offshore Palawan, Philippines), Mar. Petrol. Geol., 21, 1-22, https://doi.org/10.1016/j.marpetgeo.2003.11.012, 2004.

Fournier, F., Borgomano, J., and Montaggioni, L. F.: Development patterns and controlling factors of Tertiary carbonate buildups: Insights from high-resolution 3D seismic and well data in the Malampaya gas field (offshore Palawan, Philippines), Sediment. Geol., 175, 189-215, https://doi.org/10.1016/j.sedgeo.2005.01.009, 2005.

Gliniak, P., Urbaniec, A.: Oxford biohermal structures in the area Bochnia-Sędziszów in seismic 3D recording, Nafta-Gaz, 10, 545-556, 2001.

Gliniak, P. and Urbaniec, A.: Geophysical characteristic of Oxfordian bioherms in the Carpathian foreland area in the aspect of new techniques of hydrocarbons searching (in Polish with English summary), Nafta-Gaz, 61, 343-348, 2005.

Gliniak, P., Laskowicz, R., and Urbaniec, A.: Upper Jurassic organic constructions in Bochnia - Dębica area - possibility of recognition on seismic section and exploration prospections of hydrocarbon reservoirs (in Polish, with English summary), Institute of Oil and Gas - Kraków Special Paper, 110, 161-165, 2000.

Gliniak, P., Laskowicz, A., Urbaniec, A., Such, P., and Leśniak, G.: Reservoir rocks and facies development of the Upper Jurassic carbonate in Zawada - Lękawica area, Nafta-Gaz, 11, 597-606, 2001

Gliniak P., Laskowicz, R., Urbaniec, A., Leśniak, G., and Such, P.: The facies development and reservoir properties in Late Jurassic carbonate sediments in the central Carpathian foreland, in: Deformation, Fluid Flow and Reservoir Appraisal in Foreland Fold, edited by: Swennen, R., Roure, F., and Granath, J. W., AAPG Hedberg Ser., 1, 347-355, 2004.

Gliniak, P., Gutowski, J., and Urbaniec, A.: Organic buildups recognized upon well and seismic data within the Upper Jurassic formations of the Carpathian foreland, Poland; perspectives for hydrocarbon exploration, Volumina Jurassica, 3, 29-43, 2005.

Golonka, J.: The Upper Jurassic microfacies in the Carpathian foreland, Biuletyn Instytutu Geologicznego, 310, 5-38, 1978.

Golonka, J.: Plate tectonic evolution of the southern margin of Eurasia in the Mesozoic and Cenozoic, Tectonopysics, 381, 235-273, https://doi.org/10.1016/j.tecto.2002.06.004, 2004.

Golonka J., Oszczypko, N., and Ślączka, A.: Geodynamic evolution and paleogeography of the Carpathian-Panonian region - a global perspective, Slovak Geolog. Mag., 6, 139-142, 2000.

Grötsch, J. and Mercadier, C.: Integrated 3-D reservoir modeling based on 3-D seismic: The Tertiary Malampaya and Camago buildups, offshore Palawan, Philippines, AAPG Bull., 83, 1703-1727, https://doi.org/10.1306/E4FD4247-1732-11D78645000102C1865D, 1999

Guo, L., Vincent, S. J., and Lavrishchev, V.: Upper Jurassic Reefs from the Russian Western Caucasus: Implications for the Eastern Black Sea, Turk. J. Earth Sci., 20, 629-653, https://doi.org/10.3906/yer-1012-5, 2011.

Gutowski, J. and Koyi, H.: Influence of oblique basement strikeslip faults on the Mesozoic evolution of the south-eastern segment of the Mid-Polish Trough, Basin Res., 19, 67-86, https://doi.org/10.1111/j.1365-2117.2007.00312.x, 2007.

Gutowski, J., Popadyuk, I. V., and Olszewska, B.: Late Jurassicearliest Cretaceous evolution of the epicontinental sedimentary basin of southeastern Poland and Western Ukraine, Geol. Q., 49, 31-44, https://doi.org/10.7306/gq.v49i1.7364, 2005.

Gutowski, J., Złonkiewicz, Z., Matyja, B. A., Pieńkowski, G., Radwańska, U., Radwański, A., and Wierzbowski, A.: Field trip B2 - Upper Jurassic shallow-water carbonate platform and open shelf facies. Shallow water carbonates of the Holy Cross Mountains, in: Field trip guidebook of the 7th International Congress on the Jurassic System, edited by: Wierzbowski, A., Aubrecht, R., Golonka, J., Gutowski, J., Krobicki, M., Matyja, B. A., Pieńkowski, G., and Uchman, A., Kraków, Poland, 169-198, 2006.

Gutowski, J., Urbaniec, A., Złonkiewicz, Z., Bobrek, L., Świetlik, B., and Gliniak, P.: Upper Jurassic and Lower Cretaceous of the Middle Polish Carpathian Foreland, Biuletyn Państwowego Instytutu Geologicznego, 426, 1-26, 2007.

Gwinner, M. P.: Carbonate rocks of the Upper Jurassic in SWGermany, in: Sedimentology of parts of Central Europe, edited by: Müller, G., Verlag Waldemar Kramer, Frankfurt am Main, 193-207, 1971.

Handford, C. R. and Loucks, R. G.: Carbonate Depositional Sequences and Systems Tracts - Responses of Carbonate Platforms to Relative Sea-Level Changes, in: Carbonate sequence stratigraphy: Recent development and applications, edited by: Loucks, R. G. and Sarg, J. F., AAPG Memoir, 57, 3-41, https://doi.org/10.1306/M57579C1, 1993.

Hartmann, H., Buness, H., Krawczyk, C. M., and Schulz, R.: 3-D seismic analysis of a carbonate platform in the Molasse Basin - reef distribution and internal separation with seismic attributes, Tectonophysics, 572-573, 16-25, https://doi.org/10.1016/j.tecto.2012.06.033, 2012.

Isern, A. R., Anselmetti, F. S., and Blum, P.: A Neogene carbonate platform, slope, and shelf edifice shaped by sea level and ocean currents, Marion Plateau (northeast Australia), in: Seismic imaging of carbonate reservoirs and systems, edited by: Eberli, G. P., Massaferro, J. L., and Sarg, J. F., AAPG Memoir, 81, 291-307, https://doi.org/10.1306/M81928, 2004

Jędrzejowska-Tyczkowska, H., Misiarz, P., Golonka, J., and Przejczowska, A.: Outrop information and seismic analogs in analysis of Jurassic buildups (Poland), in: Proceedings of the 67th EAGE Conference \& Exhibition, Madrid, https://doi.org/10.3997/22144609-pdb.1.P295, 2005.

Jędrzejowska-Tyczkowska, H., Golonka, J., Misiarz, P., Krobicki, M., Matyszkiewicz, J., Olszewska, B., Przejczowska, A., and Oszczypko, N.: Upper Jurassic carbonate buildups in the Carpathian foreland in Poland: geological and geophysical setting, Volumina Jurassica, 4, 92-93, 2006.

Jurkowska, A.: Inoceramid stratigraphy and depositional architecture of the Campanian and Maastrichtian of the Miechów Synclinorium (southern Poland), Acta Geol. Pol., 66, 59-84, https://doi.org/10.1515/agp-2015-0025, 2016.

Kendall, C. G. St. C. and Schlager, W.: Carbonates and relative changes in sea level, Mar. Geol., 44, 181-212, https://doi.org/10.1016/0025-3227(81)90118-3, 1981.

Kiessling, W., Flügel, E., and Golonka, J.: Paleoreef Maps: Evaluation of a Comprehensive Database on Phanerozoic Reefs, AAPG 
Bull., 83, 1552-1587, https://doi.org/10.1306/E4FD4215-173211D7-8645000102C1865D, 1999.

Kochman, A. and Matyszkiewicz, J.: Experimental method for estimation of compaction in the Oxfordian bedded limestones of the southern Kraków-Częstochowa Upland, Southern Poland, Acta Geol. Pol., 63, 681-696, https://doi.org/10.2478/agp-2013-0029, 2013.

Koša, E.: Sea-level changes, shoreline journeys, and the seismic stratigraphy of Central Luconia, Miocene-present, offshore Sarawak, NW Borneo, Mar. Petrol. Geol., 59, 35-55, https://doi.org/10.1016/j.marpetgeo.2014.07.005, 2015.

Krajewski, M. and Schlagintweit, F.: Crescentiellamicrobial-cement microframeworks in the Upper Jurassic reefs of the Crimean Peninsula, Facies, 64, 21, https://doi.org/10.1007/s10347-018-0534-3, 2018.

Krajewski, M., Matyszkiewicz, J., Król, K., and Olszewska, B.: Facies of the Upper Jurassic-Lower Cretaceous deposits from the southern part of the Carpathian Foredeep basement in the Kraków-Rzeszów area (southern Poland), Ann. Soc. Geol. Pol., 81, 269-290, 2011.

Krajewski, M., Olchowy, P., and Felisiak, I.: Late Jurassic facies architecture of the Złoczew Graben: implications for evolution of the tectonic-controlled northern peri-Tethyan shelf (Upper Oxfordian-Lower Kimmeridgian, Poland), Facies, 62, 4, https://doi.org/10.1007/s10347-015-0455-3, 2016.

Krajewski, M., Olchowy, P., Zatoń, M., and Bajda, T.: Kimmeridgian hardground-sequence boundary from the Mesozoic margin of the Holy Cross Mountains (central Poland): implications for the evolution of the northern Tethyan carbonate shelf, Facies, 63, 15, https://doi.org/10.1007/s10347-017-0496-x, 2017.

Krajewski, M., Olchowy, P. and Rudziński, D.: Sedimentary successions in the Middle-Upper Oxfordian reef deposits from the southern part of the Kraków-Częstochowa Upland (Southern Poland), Geol. Q., 62, 653-668, https://doi.org/10.7306/gq.1429, 2018.

Krzywiec, P.: Contrasting tectonic and sedimentary history of the central and eastern parts of the Polish Carpathian Foredeep Basin - results of seismic data interpretation, Mar. Petrol. Geol., 18, 13-38, https://doi.org/10.1016/S0264-8172(00)00037-4, 2001.

Krzywiec, P.: Mid-Polish Trough inversion - seismic examples, main mechanisms and its relationship to the Alpine - Carpathian collision, in: Continental Collision and the Tectonosedimentary Evolution of Forelands, edited by: Bertotti, G., Schulmann, K., and Cloetingh, S., EGU Stephan Mueller Special Publication Series, 1, 151-165, https://doi.org/10.5194/smsps-1-151-2002, 2002.

Krzywiec, P.: Devonian-Cretaceous repeated subsidence and uplift along the Tornquist-Teisseyre Zone in SE Poland - insight from seismic data interpretation, Tectonophysics, 475, 142-159, https://doi.org/10.1016/j.tecto.2008.11.020, 2009.

Krzywiec, P., Gutowski, J., Walaszczyk, I., Wróbel, G., and Wybraniec, S.: Tectonostratigraphic model of the Late Cretaceous inversion along the Nowe Miasto-Zawichost Fault Zone, SE Mid-Polish Trough, Geol. Q., 53, 27-48, 2009.

Krzywiec, P., Stachowska, A., and Stypa, A.: The only way is up - on Mesozoic uplifts and basin inversion events in SE Poland, in: Mesozoic Resource Potential in the Southern Permian Basin, edited by: Kilhams, B., Kukla, P. A., Mazur, S., McKie, T., Mi- jnlieff, H. F., and Van Ojik, K., Geol. Soc. London Spec. Publ., 469, 33-57, https://doi.org/10.1144/SP469.14, 2018.

Kusumastuti, A., Van Rensbergen, P., and Warren, J. K.: Seismic sequence analysis and reservoir potential of drowned Miocene carbonate platforms in the Madura Strait, East Java, Indonesia, APPG Bull., 86, 213-232, https://doi.org/10.1306/61EEDA94173E-11D7-8645000102C1865D, 2002.

Kutek, J.: Le probleme du Rauracien et de l'Astartien de Pologne, Rocznik Polskiego Towarzystwa Geologicznego, 35, 263-272, 1965.

Kutek, J.: The Kimmeridgian and Upper Oxfordian in the SW margins of the Holy Cross Mts., (Central Poland). Part I. Stratigraphy, Acta Geol. Pol., 18, 493-586, 1968.

Kutek, J.: The Kimmeridgian and Upper Oxfordian in the SW margins of the Holy Cross Mts., (Central Poland). Part II. Paleogeography, Acta Geol. Pol., 19, 221-321, 1969.

Kutek, J.: Jurassic tectonic events in south-eastern Poland, Acta Geol. Pol., 44, 67-221, 1994.

Kutek, J.: The Polish Mesozoic Rift Basin, in: Peri-Tethys Memoir 6: Peri-Tethyan Rift/Wrench Basins and Passive Margins, edited by: Ziegler, P. A., Cavazza, W., Robertson, A. H. F., and Crasquin-Soleau, S., Memoir Mus. Natl. Hist., 186, 213-236, 2001.

Kutek, J. and Głazek, J.: The Holy Cross Area, Central Poland, in the Alpine Cycle, Acta Geol. Pol., 22, 603-653, 1972.

Lach, A.: Master Log for Chopin-1 well, unpublished technical report, GEOKRAK, 2011a.

Lach, A.: Master Log for Belvedere-1 well, unpublished technical report, GEOKRAK, 2011 b.

Leinfelder, R. R., Krautter, M., Laternser, R., Nose, M., Schmid, D. U., Schweigert, G., Werner, W., Keupp, H., Brugger, H., Herrmann, R., Rehfeld-Kiefer, U., Schroeder, J. H., Reinhold, C., Koch, R., Zeiss, A., Schweizer, V., Christmann, H., Menges, G., and Luterbacher, H.: The origin of Jurassic reefs: current research developments and results, Facies, 31, 1-56, https://doi.org/10.1007/bf02536932, 1994.

Leinfelder, R. R., Werner, W., Nose, M., Schmid, D. U., Krautter, M., Laternser, R., Takacs, M., and Hartmann, D.: Paleoecology, growth parameters and dynamics of coral, sponge and microbolite reefs from the Late Jurassic, Göttinger Arb. Geol. Paläont. Sb., 2, 227-248, 1996.

Leinfelder, R. R., Schmid, D. U., Nose, M., and Werner, W.: Jurassic reef patterns - the expression of a changing globe, in: Phanerozoic reef patterns, edited by: Kiessling, W., Flügel, E., and Golonka, J., SEPM Spec. Publ., 72, 465-520, https://doi.org/10.2110/pec.02.72.0465, 2002.

Lott, G. K., Wong, T. E., Dusar, M., Andsbjerg, J., Mönnig, E., Feldman-Olszewska, A., and Verreussel, R. M. C. H.: Jurassic, in: Petroleum geological atlas of the Southern Permian Basin Area, edited by: Doornenbal, J. C. and Stevenson, A.G., EAGE Publications, Houten, 175-193, 2010.

Lüschen, E., Wolfgramm, M., Fritzer, T., Dussel, M., Thomas, R., and Schulz, R.: 3D seismic survey explores geothermal targets for reservoir characterization at Unterhaching, Munich, Germany, Geothermics, 50, 167-179, https://doi.org/10.1016/j.geothermics.2013.09.007, 2014.

Macurda, D. B.: Carbonate Seismic Facies Analysis, in: Carbonate seismology, edited by: Marfurt, K. J. 
and Palaz, A., SEG Geophys. Dev. Ser., 6, 95-119, https://doi.org/10.1190/1.9781560802099, 1997.

Marek, S. and Pajchlowa, M. (Eds.): Epicontinental Permian and Mesozoic in Poland, Prace Państwowego Instytutu Geologicznego, 153, 1-452, 1997.

Matyja, B. A.: The Oxfordian in the south-western margin of the Holy Cross Mts, Acta Geol. Pol., 27, 41-64, 1977.

Matyja, B. A.: Development of the Mid-Polish Trough versus Late Jurassic evolution in the Carpathian Foredeep area, Geol. Q., 51, 49-62, 2009.

Matyja, B. A. and Barski, M.: Stratygrafia górnej jury podłoża zapadliska przedkarpackiego, Tomy Jurajskie, 4, 39-50, 2007.

Matyja, B. A. and Pisera, A.: Late Jurassic European sponge megafacies: general perspective, in: 3rd Intern. Symp. Jurassic Stratigraphy Abstracts, Poitiers, France, 81 pp., 1991.

Matyja, B. A. and Tarkowski, R.: Lower and Middle Oxfordian ammonite biostratigraphy at Zalas in the Crakow Upland, Acta Geol. Pol., 31, 1-14, 1981.

Matyja, B. A. and Wierzbowski, A.: Biogeographic differentiation of the Oxfordian and Early Kimmeridgian ammonite faunas of Europe, and its stratigraphic consequences, Acta Geol. Pol., 45, $1-8,1995$.

Matyja, B. A. and Wierzbowski, A.: Sea bottom relief and bathymetry of Late Jurassic sponge megafacies in Poland, Geores. Forum, 1-2, 333-340, 1996.

Matyja, B. A. and Wierzbowski, A.: Open shelf facies of the Polish Jura Chain, in: Field trip guidebook of the 7th International Congress on the Jurassic System, edited by: Wierzbowski, A., Aubrecht, R., Golonka, J., Gutowski, J., Krobicki, M., Matyja, B. A., Pieńkowski, G., and Uchman, A., Kraków, Poland, 198206, 2006.

Matyja, B. A., Gutowski, J., and Wierzbowski, A.: The open shelfcarbonate platform succession at the Oxfordian/Kimmeridgian boundary in the SW margin of the Holy Cross Mts: stratigraphy, facies and ecological implications, Acta Geol. Pol., 39, 29-48, 1989.

Matyja, B. A., Wierzbowski, A., Radwańska, U., and Radwański, A.: Stop B2.8 - Małogoszcz, large quarry of cement works (Lower and lowermost Upper Kimmeridgian), in: Field trip guidebook of the 7th International Congress on the Jurassic System, edited by: Wierzbowski, A., Aubrecht, R. , Golonka, J., Gutowski, J., Krobicki, M., Matyja, B. A., Pieńkowski, G., and Uchman, A., Kraków, Poland, 190-198, 2006.

Matyszkiewicz, J.: Sedimentation and diagenesis of the Upper Oxfordian cyanobacterial sponge-limestones in Piekary near Kraków, Ann. Soc. Geol. Pol., 59, 201-232, 1989.

Matyszkiewicz, J.: Genesis of stromatactis in an Upper Jurassic carbonate buildup (Mlynka, Cracow region, Southern Poland): internal reworking and erosion of organic growth cavities, Facies, 28, 87-96, 1993.

Matyszkiewicz, J.: The significance of Saccocoma-calciturbidites for the analysis of the Polish Epicontinental Late Jurassic Basin: an example from the Southern Cracow-Wielun Upland (Poland), Facies, 34, 23-40, https://doi.org/10.1007/bf02546155, 1996.

Matyszkiewicz, J.: Microfacies, sedimentation and some aspects of diagenesis of Upper Jurassic sediments from the elevated part of the Northern peri-Tethyan Shelf: a comparative study on the Lochen area (Schwäbische Alb) and the Cracow area (Cracow-
Wielun Upland, Poland), Berliner geowissenschaftliche Abhandlungen, 21, 1-111, 1997a.

Matyszkiewicz, J.: Stromatactis cavities and stromatactis-like cavities in the Upper Jurassic carbonate buildups at Młynka and Zabierzów (Oxfordian, southern Poland), Ann. Soc. Geol. Pol., 67, 45-55, 1997b.

Matyszkiewicz, J.: Sea-bottom relief versus differential compaction in ancient platform carbonates: a critical reassessment of an example form Upper Jurassic of the Cracow-Wielun Upland, Ann. Soc. Geol. Pol., 69, 63-79, 1999.

Matyszkiewicz, J.: A role of the Cracovian region in the Late Jurassic sedimentation of the Cracow-Częstochowa Upland (southern Poland), Przegląd Geologiczny, 49, 724-727, 2001.

Matyszkiewicz, J.: The Cracow-Częstochowa Upland (Southern Poland) - The Land of White Cliffs and Caves, Przegląd Geologiczny, 56, 647-652, 2008.

Matyszkiewicz, J. and Felisiak, I.: Microfacies and diagenesis of an Upper Oxfordian carbonate buildup in Mydlniki (Cracow area, Southern Poland), Facies, 27, 179-190, https://doi.org/10.1007/bf02536811, 1992.

Matyszkiewicz, J. and Kochman, A.: Pressure dissolution features in Oxfordian microbial-sponge buildups with pseudonodular texture, Kraków Upland, Poland, Ann. Soc. Geol. Pol., 86, 355-377, https://doi.org/10.14241/asgp.2016.008, 2016.

Matyszkiewicz, J., Krajewski, M., and Kędzierski, J.: Origin and evolution of an Upper Jurassic complex of carbonate buildups from Zegarowe Rocks (Kraków-Wieluń Upland, Poland), Facies, 52, 249-263, https://doi.org/10.1007/s10347-005-0038-9, 2006.

Matyszkiewicz, J., Kochman, A., and Duś, A.: Influence of local sedimentary conditions on development of microbialites in the Oxfordian carbonate buildups from the southern part of the Kraków-Częstochowa Upland (south Poland), Sediment. Geol., 263-264, 109-132, https://doi.org/10.1016/j.sedgeo.2011.08.005, 2012.

Matyszkiewicz, J., Kochman, A., Rzepa, G., Gołębiowska, B., Krajewski, M., Gaidzik, K., and Żaba, J.: Epigenetic silicification of the Upper Oxfordian limestones in the Sokole Hills (Kraków-Częstochowa Upland): relationship to facies development and tectonics, Acta Geol. Pol., 65, 181-203, https://doi.org/10.1515/agp-2015-0007, 2015a.

Matyszkiewicz, J., Felisiak, I., Hoffmann, M., Kochman, A., Kołodziej, B., Krajewski, M., and Olchowy, P.: Transgressive Callovian succession and Oxfordian microbial-sponge carbonate buildups in the Kraków Upland, in: Guidebook for field trips accompanying 31st IAS Meeting of Sedimentology, edited by: Haczewski, G., Polish Geological Society, Kraków, Poland, 5174, 2015 b.

Matyszkiewicz, J., Krajewski, M., Kochman, A., Kozłowski, A., and Duliński, M.: Oxfordian neptunian dykes with brachiopods from the southern part of the Kraków-Częstochowa Upland (southern Poland) and their links to hydrothermal vents, Facies, 62, 12, https://doi.org/10.1007/s10347-016-0464-x, 2016.

Mazur, S., Mikołajczak, M., Krzywiec, P., Malinowski, M., Buffenmyer, V., and Lewandowski, M.: Is the Teisseyre-Tornquist Zone an ancient plate boundary of Baltica?, Tectonics, 34, 2465-2477, https://doi.org/10.1002/2015TC003934, 2015.

Mikucka-Reguła, T.: Dokumentacja wynikowa $\mathrm{z}$ otworów: WODZISŁAW 1, WODZISŁAW 2, WODZISŁAW 3 , 
KALINA 1, KLONÓW 1, WĘCHADŁÓW 1, LIPÓWKA 1, RACŁAWICE 2, Archival report: borehole studies, Cat. SW/P/933, Arch. PGNiG S.A., Warszawa, 1968.

Misiarz, P.: Coherence analysis of 3D seismic record for detection and characterisation of biohermal objects and structural discontinuities in the Carpathian Foreland, Nafta-Gaz, 59, 70-79, 2003.

Misiarz, P., Jędrzejowska-Tyczkowska, H., Oszczypko, N., Golonka, J., Olszewska, B., and Matyszkiewicz, J.: Oxfordian bioherms from the central part of the Carpathian foreland (Poland) - seismic modeling results, in: Proceedings of the AAPG Regional Conference with GSA, Prague, Czech Republic, 94 pp., 2004.

Morycowa, E. and Moryc, W.: The Upper Jurassic sediments in the foreland of the Polish Carpathians (Sandomierz Basin), Ann. Soc. Geol. Pol., 46, 231-288, 1976.

Morycowa, E. and Moryc, W.: Upper Jurassic-Lower Cretaceous carbonate complex in Dąbrowa Tarnowska-Szczucin area (Carpathian foreland), Biuletyn Państwowego Instytutu Geologicznego, 447, 25-48, 2011.

Myśliwiec, M., Borys, Z., Bosak, B., Liszka, B., Madej, K., Maksym, A., Oleszkiewicz, K., Pietrusiak, M., Plezia, B., Staryszak, G., Świętnicka, G., Zielińska, C., Zychowicz, K., Gliniak, P., Florek, R., Zacharski, J., Urbaniec, A., Górka, A., Karnkowski P., and Karnkowski, P. H.: Hydrocarbon resources of the Polish Carpathian Foredeep: Reservoirs, traps, and selected hydrocarbon fields, in: The Carpathians and their foreland: Geology and hydrocarbon resources, edited by: Golonka, J., and Picha, F. J., AAPG Memoir, 84, 351-393, https://doi.org/10.1306/985613M843073, 2006.

Neuhaus, D., Borgomano, J., Jauffred, J.-C., Mercadier, C., Olotu, S., and Grötsch, J.: Quantitative seismic reservoir characterization of an Oligocene-Miocene carbonate buildup: Malampaya field, Philippines, in: Seismic imaging of carbonate reservoirs and systems, edited by: Eberli, G. P., Massaferro, J. L., and Sarg, J. F., AAPG Memoir, 81, 169-183, https://doi.org/10.1306/M81928, 2004.

Olivier N., Colombié, C., Pittet, B., and Lathuiličre, B.: Microbial carbonates and corals on the marginal French Jura platform (Late Oxfordian, Molinges section), Facies, 57, 469-492, https://doi.org/10.1007/s10347-010-0246-9, 2011.

Olszewska, B., Matyszkiewicz, J., Król, K., and Krajewski, M.: Correlation of the Upper Jurassic-Cretaceous epicontinental sediments in southern Poland and south western Ukraine based on thin sections, Biuletyn Państwowego Instytutu Geologicznego, 453, 29-80, 2012.

Pharaoh, T., Dusar, M., Geluk, M., Kockel, F., Krawczyk, C., Krzywiec, P., Scheck-Wenderoth, M., Thybo, H., Vejbæk, O., and Van Wees, J. D.: Tectonic evolution, in: Petroleum geological atlas of the Southern Permian Basin Area, edited by: Doornenbal, J. C. and Stevenson, A. G., EAGE Publications, Houten, 25-57, 2010.

Philips, T., Jackson, C. A. L., Bell, R., and Valencia, A.: Rivers, reefs, and deltas; Geomorphological evolution of the Jurassic of the Farsund Basin, offshore southern Norway, Petrol. Geosci., 26, 81-100, https://doi.org/10.1144/petgeo2018-056, 2019.

Pieńkowski, G., Schudack, M. E., Bosák, P., Enay, R., FeldmanOlszewska, A., Golonka, J., Gutowski, J., Herngreen, G. F. W., Jordan, P., Krobicki, M., Lathuiliere, B., Leinfelder, R. R., Michalík, J., Mönnig, E., Noe-Nygaard, N., Pálfy, J., Pint, A.,
Rasser, M. W., Reisdorf, A. G., Schmid, D. U., Schweigert, G., Surlyk, F., Wetzel, A., and Wong, T. E.: Jurassic In: The Geology of Central Europe, in: Volume 2: Mesozoic and Cenozoic, edited by: McCann, T., Geological Society, London, 823-922, https://doi.org/10.1144/CEV2P, 2008.

Posamentier, H. W., Laurin, P., Warmath, A., Purnama, M., and Drajat, D.: Seismic stratigraphy and geomorphology of Oligocene to Miocene carbonate buildups offshore Madura, Indonesia, in: Cenozoic carbonate systems of Australasia, edited by: Morgan, W. A., George, A. D., Harris, P. M., Kupecz, J. A., and Sarg, J. F., SEPM Spec. Publ., 95, 175-194, https://doi.org/10.2110/sepmsp.095.175, 2010.

Pożaryski, W.: Tectonics. Part 1. Polish Lowlands, in: Geology of Poland IV (in Polish only), edited by: Pożaryski, W., Wydawnictwa Geologiczne, Warszawa, Poland, 2-34, 1974.

Pożaryski, W.: The early Alpine Laramide Epoch in the Platform development east of the Fore Sudetic and Silesian-Cracovian monoclines, in: Geology of Poland IV, edited by: Pożaryski, W., Wydawnictwa Geologiczne, Warszawa, Poland, 351-416, 1977.

Pożaryski, W. and Brochwicz-Lewiński, W.: On the Polish Trough, Geol. Mijnbouw, 57, 545-557, 1978.

Pożaryski, W. and Brochwicz-Lewiński, W.: On the Mid-Polish Aulacogen, Geol. Q., 23, 271-290, 1979.

Pożaryski, W. and Żytko, K.: On the Mid-Polish Aulacogen and the Carpathian Geosyncline, Acad. Pol. Sci. Bull. Sér. Sci. Géol. Géogr., 28, 303-316, 1981.

Rafaelsen, B., Elvebakk, G., Andreassen, K., Stemmerik, L., Colpaert, A., and Samuelsberg, T. J.: From detached to attached carbonate buildup complexes - 3D seismic data from the upper Palaeozoic, Finnmark Platform, southwestern Barents Sea, Sediment. Geol., 206, 17-32, https://doi.org/10.1016/j.sedgeo.2008.03.001, 2008.

Rankey, E. C., Schlaich, M., Mokhtar, S., Ghon, G., Ali, S. H., and Poppelreiter, M.: Seismic architecture of a Miocene isolated carbonate platform and associated off-platform strata (Central Luconia Province, offshore Malaysia), Mar. Petrol. Geol., 102, 477495, https://doi.org/10.1016/j.marpetgeo.2019.01.009, 2019.

Read, J. F.: Carbonate Platform Facies Models, AAPG Bull., 69, 1-21, https://doi.org/10.1306/AD461B79-16F7-11D7$8645000102 \mathrm{C} 1865 \mathrm{D}, 1985$.

Resak, M., Narkiewicz, M., and Littke, R.: New basin modelling results from the Polish part of the Central European Basin system: implications for the Late Cretaceous-Early Paleogene structural inversion, Int. J. Earth Sci., 97, 955-972, https://doi.org/10.1007/s00531-007-0246-3, 2008.

Rosleff-Soerensen, B., Reuning, L., Back, S., and Kukla, P.: Seismic geomorphology and growth architecture of a Miocene barrier reef, Browse Basin, NW-Australia, Mar. Petrol. Geol., 29, 233254, https://doi.org/10.1016/j.marpetgeo.2010.11.001, 2012.

Saqab, M. M. and Bourget, J.: Seismic geomorphology and evolution of early mid Miocene isolated carbonate build-ups in the Timor Sea, North West Shelf of Australia, Mar. Geol., 369, 224 245, https://doi.org/10.1016/j.margeo.2016.06.007, 2016.

Sarg, J. F.: Carbonate Sequence Stratigraphy, in: Sea-Level Changes: An Integrated Approach, edited by: Wilgus, C. K., Hastings, B. S., Posamentier, H., Van Wagoner, J., Ross, C. A., and Kendall, C. G. St. C., SEPM Spec. Publ., 42, 7-108, https://doi.org/10.2110/pec.88.01.0155, 1988. 
Sayago, J., Di Luccia, M., Mutti, M., Sitta, A., Cotti, A., and Frijia, G.: Late Paleozoic seismic sequence stratigraphy and paleogeography of the paleo-Loppa High in the Norwegian Barents Sea, Mar. Petrol. Geol., 97, 192-208, https://doi.org/10.1016/j.marpetgeo.2018.05.038, 2018.

Scheck-Wenderoth, M., Krzywiec, P., Zülke, R., Maystrenko, Y., and Frizheim, N.: Permian to Cretaceous tectonics, in: The Geology of Central Europe. Volume 2: Mesozoic and Cenozoic, edited by: McCann, T., Geological Society, London, UK, 9991030, https://doi.org/10.1144/CEV2P, 2008.

Schlager, W.: Carbonate sedimentology and sequence stratigraphy, SEPM Concept. Sedimentol. Paleontol., 8, 209 pp., https://doi.org/10.2110/csp.05.08, 2005.

Shahzad, K., Betzler, C., Ahmed, N., Qayyum, F., Spezzaferri, S., and Qadir, A.: Growth and demise of a Paleogene isolated carbonate platform of the Offshore Indus Basin, Pakistan: effects of regional and local controlling factors, Int. J. Earth Sci. (Geol. Rundsch.), 107, 481-504, https://doi.org/10.1007/s00531-0171504-7, 2018.

Shahzad, K., Betzler, C., and Qayyum, F.: Controls on the Paleogene carbonate platform growth under greenhouse climate conditions (Offshore Indus Basin), Mar. Petrol. Geol., 101, 519-539, https://doi.org/10.1016/j.marpetgeo.2018.12.025, 2019.

Szwed, Z. and Wójcik, A.: Geological Log: well Chopin-1, unpublished technical report, NAFTGAZ Wołomin, 2011a.

Szwed, Z. and Wójcik, A.: Daily report: well Chopin-1, unpublished technical report, PNiG Jasło Sp. z o.o., 2011 b.

Trammer, J.: Lower to Middle Oxfordian sponges of the Polish Jura, Acta Geol. Pol., 32, 1-39, 1982.

Trammer, J.: Sponge bioherms in the Jasna Góra Beds (Oxfordian of the Polish Jura Chain), Przegl. Geol., 33, 78-81, 1985.

Trammer, J.: Middle to Upper Oxfordian sponges of the Polish Jura, Acta Geol. Pol., 39, 49-92, 1989.

Urban, E. and Wandas, T.: Dokumentacja wynikowa otworu: Michałów 1, Michałow 3, Archival report: borehole studies, Cat. SW/P/1009, Arch. PGNiG S.A., Warszawa, 1968.

Urbaniec, A.: Lithofacial development of the Upper Jurassic and Lower Cretaceous deposits in the Dąbrowa Tarnowska-Dębica area based on the 3D seismic interpretations, unpublished PhD Thesis, Faculty of Geology, Geophysics and Environmental Protection of AGH, Kraków, 2019.

Van Tuyl, J., Alves, T. M., and Cherns, L.: Geometric and depositional responses of carbonate build-ups to Miocene sea level and regional tectonics offshore northwest Australia, Mar. Petrol. Geol., 94, 144-165, https://doi.org/10.1016/j.marpetgeo.2018.02.034, 2018.

Van Tuyl, J., Alves, T., Cherns, L., Antonatos, G., Burgess, P., and Masiero, I. Geomorphological evidence of carbonate buildup demise on equatorial margins: A case study from offshore northwest Australia, Mar. Petrol. Geol., 104, 125-149, https://doi.org/10.1016/j.marpetgeo.2019.03.006, 2019.

Veeken, P. and Van Moerkerken, B.: Seismic Stratigraphy and Depositional Facies Models, EAGE Publications, Houten, 494 pp., 2013.

Wessely, G.: Geologie von Niederösterreich, Geologische Bundesanstalt, Wien, 416 pp., 2006.
Wierzbowski, A., Atrops, F., Grabowski, J., Hounslow, M., Matyja, B. A., Olóriz, F., Page, K., Parent, H., Rogov, M. A., Schweigert, G., Villaseñor, A. B., Wierzbowski, H., and Wright, J. K.: Towards a consistent Oxfordian-Kimmeridgian global boundary: current state of knowledge, Volumina Jurassica, 14, 15-50, 2016.

Wierzbowski, H.: Seawater temperatures and carbon isotope variations in central European basins at the Middle-Late Jurassic transition (Late Callovian-Early Kimmeridgian), Palaeogeogr. Palaeocl., 440, 506-523, https://doi.org/10.1016/j.palaeo.2015.09.020, 2015.

Wu, S., Yuan, S., Zhang, G., Ma, Y., Mi, L., and Xu, N.: Seismic characteristics of a reef carbonate reservoir and implications for hydrocarbon exploration in deepwater of the Qiongdongnan Basin, northern South China Sea, Mar. Petrol. Geol., 26, 817 823, https://doi.org/10.1016/j.marpetgeo.2008.04.008, 2009.

Yubo, M. Shiguo, W., Fuliang, L., Dongdong, D., Qiliang, S., Yintao, L., and Mingfeng, G.: Seismic characteristics and development of the Xisha carbonate platforms, northern margin of the South China Sea, J. Asian Earth Sci., 40, 770-783, https://doi.org/10.1016/j.jseaes.2010.11.003, 2011.

Zampetti, V., Schlager, W., van Konijnenburg, J. H., and Everts, A. J.: Depositional history and origin of porosity in a Miocene carbonate platform of Central Luconia, offshore Sarawak, Bull. Geol. Soc. Malaysia, 47, 139-152, https://doi.org/10.7186/bgsm47200311, 2003.

Zampetti, V., Schlager, W., van Konijnenburg, J. H., and Everts, A. J.: Architecture and growth history of a Miocene carbonate platform from 3D seismic reflection data; Luconia Province, offshore Sarawak, Malaysia, Mar. Petrol. Geol., 21, 517-534, https://doi.org/10.1016/j.marpetgeo.2004.01.006, 2004.

Ziegler, P. A.: Geological atlas of western and central Europe, Shell International Petroleum Maatschappij B.V., Geological Society, London, 239 pp., 1990.

Zimmer, W. and Wessely G.: Exploration results in thrust- and subthrust complexes in the Alps and below the Vienna Basin in Austria, in: Oil and gas in Alpidic Thrustbelts and Basins of Central and Eastern Europe, edited by: Wessely, G. and Liebl, W., EAGE Special Pub. 5, Geol. Soc., London, 81-107, https://doi.org/10.3997/2214-4609.201410141, 1996.

Złonkiewicz, Z.: Evolution of the Miechów Depression basin in the Jurassic as a result of regional tectonical changes, Przegląd Geologiczny, 54, 534-540, 2006.

Złonkiewicz, Z.: The Callovian and Upper Jurassic section in the Nida Trough, Przegląd Geol., 57, 521-530, 2009.

Żelaźniewicz, A., Aleksandrowski, P., Buła, Z., Karnkowski, P., Konon, A., Oszczypko, N., Ślączka, A., Żaba, J., and Żytko, K.: Tectonic subdivision of Poland, Komitet Nauk Geologicznych PAN, Wrocław, Poland, 60 pp., 2011.

Żytko K., Gucik, S., Ryłko, W., Oszczypko, N., Zając, R., Garlicka, I., Nemčok, J., Elias, M., Mencik, E., Dvorak, J., Stranik, Z., Rakus, M., and Matejovska, O.: Geological map of the Western Outer Carpathians and their foreland without Quaternary formations (1:500000), in: Geological Atlas of the Western Outer Carpathians and their Foreland, edited by: Poprawa, D. and Nemčok, J., Polish Geological Institute, Warszawa, Poland, 1988. 